\title{
Biophilic Architecture for restoration and therapy within the built environment: A Review
}

\author{
Farhan Asim \\ Research Scholar \\ Department of Architecture \& Planning \\ Indian Institute of Technology Roorkee, India \\ Email: fasim@ar.iitr.ac.in \\ Contact: $+91-8948318668$ \\ ORCID: 0000-0001-9424-9445 \\ Venu Shree \\ Assistant Professor \\ Department of Architecture \\ National Institute of Technology Hamirpur, India \\ Email:venushree@nith.ac.in \\ Contact: +91-9882553931
}

\begin{abstract}
Can 'restoration and therapy in design' signify something more than the places like hospitals and healing gardens? Can those restorative environments be brought inside the working and living environments to mitigate the psychological problem at the source? The main objective of this paper is to look at the strategies and developments of Biophilic design with respect to therapy and restoration in order to achieve sustainability in terms of quality of life within the immediate built-environment. The paper explores the mental health issues under the domains of built-environment and indoor environment with respect to their connection with nature. Biophilic design has gained a favourable momentum within the last four decades and is now visualised as a medium that bridges the gap between humans and the nature. Out of a variety of measures of sustainable environmental design, biophilic design focuses on the end-results of naturally nurtured or inspired habitats and workplaces. It embodies strategies of Green and Intelligent buildings, works as a mitigation strategy for foul indoor environment and establishes
\end{abstract}


the vision that veristic sustainability can only be achieved if there is qualitative control over human physiological prosperity and psychological health. In context of work efficiency, preference and productivity within the indoor environment, it is seen as a promoter of constructive thoughts and enhancer of creativity. The paper aims to enlist biophilic design and retrofitting strategies, which can improve cognitive function, reduce stress and provide mental peace within the built environment.

\section{KEYWORDS}

Biophilia; biophilic design; sustainability; sustainable architecture; built environment; wellbeing; restorative environment.

\section{INTRODUCTION}

The Agenda 2030 of U.N. has given priority to health and well-being under its 'Goal 3' for targeted sustainable development, which has to be ensured for all. According to a majority of researchers, health and social prosperity are important aspects of the $21^{\text {st }}$ century human population, where they are packed closely with each other in dense urban environments with very little scope for nature to pierce through their technologically advanced lifestyles (Freudenberg, Galea, \& Vlahov, 2006; World Health Organization, 2007; Wolch, Byrne \& Newell, 2014). A significant segment of previous research in this field suggests that these urban environments create more concerns for humans regarding their health than they can solve (Sclar, Garau \& Carolini, 2005; Rydin et al., 2012; Hardoy, Mitlin \& Satterthwaite, 1992; McMichael, 2000). The inadequate spaces, which lack contact with nature, burden the psychological well-being of the human mind and leads to development of a variety of ailments (Evans, 2003; Spencer \& Baum, 1997; Stigsdotter, 2005; Martin et al., 2015). 
Human health has a causal relationship with the indoor environment, which has been evident since the mid-nineteenth century outbreak of diseases and epidemics in cities of the third world countries. Poorly designed buildings have remained a major health concern where there is partial or insufficient availability of sunlight and ventilation that resulted in alarming indoor air quality. A combination of insufficiencies in aspects of physical comfort and poor acoustics leads to the contributing factors of Sick Building Syndrome (SBS) (Boubekri, 2008; Burge, 2004). United States Environmental Protection Agency (US EPA) described 'Sick Building Syndrome (SBS)' as 'situations in which building occupants experience acute health and comfort effects that appear to be linked to time spent in a building, but no specific illness or cause can be identified. The complaints may be localized in a particular room or zone, or may be widespread throughout the building. In contrast, the term "building related illness" (BRI) is used when symptoms of diagnosable illness are identified and can be attributed directly to airborne building contaminants" (US EPA, 1991). Lindheim (1983) argued that the connection between the environmental aspects and health aspects might not always be obvious or straight. The early assumption put forward in most cases claimed that diseases are a result of direct exposure to virus carrying pathogens or unaccountable microbes until this scientific notion was challenged by new researchers, who suggested that diseases are indeed the symposium of a three-sided relationship between the host, the pathogenic virus and the environment (Dubos \& Pines, 1965; Nash, 2006).

Boubekri (2008) suggests that for humans to be optimally functional, they must be in continuous and rigorous connection with nature because that is their native environment and the indoors are comparatively new to them. Sunlight keeps humans linked to their native environment when they are functional indoors; it keeps them aware of their biological clock and maintains their circadian rhythm. Similarly, buildings are designed to act as a filter between 
humans and their native environment and they should not act as a separator or as a blockade, which resists one's access to another.

At this stage, the built environment shares a major responsibility with other ecologically conscious disciplines to intervene in the process of design and shift the direction slightly towards a healthy and sustainable model, which involves nature and its systems as the core principles of design, resulting in the associative aspects of Biophilic Architecture. Biophilic Architecture although in continuous practice since millenniums has recently rejuvenated itself as the architects and designers have begun to show interest into the possibilities of natural modifications and adaptations of built environment. The degree of application varies from retrofitting to fresh designs. Biophilic architecture involves ecology along with environmental psychology to justify the use of design elements.

The paper enlists the mental health issues caused by the built environment along with suggesting the mitigation strategies to deal with them through design. It includes the compilation of the emerging design parameters developed by several designers and researchers on an experimental basis to reduce the possibility of a built environment with poor connection with nature.

\section{METHODOLOGY}

The literature including biophilic patterns of design, behaviours and environment were identified by web searches, research papers' reference list and from articles of prominent, peer reviewed and scientifically indexed journals of environment, psychology, health and architecture.

\section{Literature Search}


Psychology, health, environment and architecture databases of SCOPUS, Web of Science and ProQuest were searched between June - August 2018 using words and synonyms of 1) Biophilia, 2) Sustainable architecture, 3) Built environment, 4) Well-being, 5) Restorative environment. The quantity of available literature was limited to article titles and abstracts for appropriateness of database searches. Approximately 6430 results were enlisted for further extension of the research.

\section{Article Selection}

Articles and literature were screened in two stages: The first stage includes examination of titles and abstracts if they mentioned biophilia and whether they were published in peer-reviewed and scientific indexed journals in order to regulate the quality of research. 314 relevant articles, books and documentations were shortlisted based upon the above criteria. The second stage screening included a strict analysis of full-text if: 1) The text mentioned E.O. Wilson's Biophilia hypothesis in relation to design adaptations. 2) The text had systematic analysis of behaviour and psychology around biophilic built environments. 


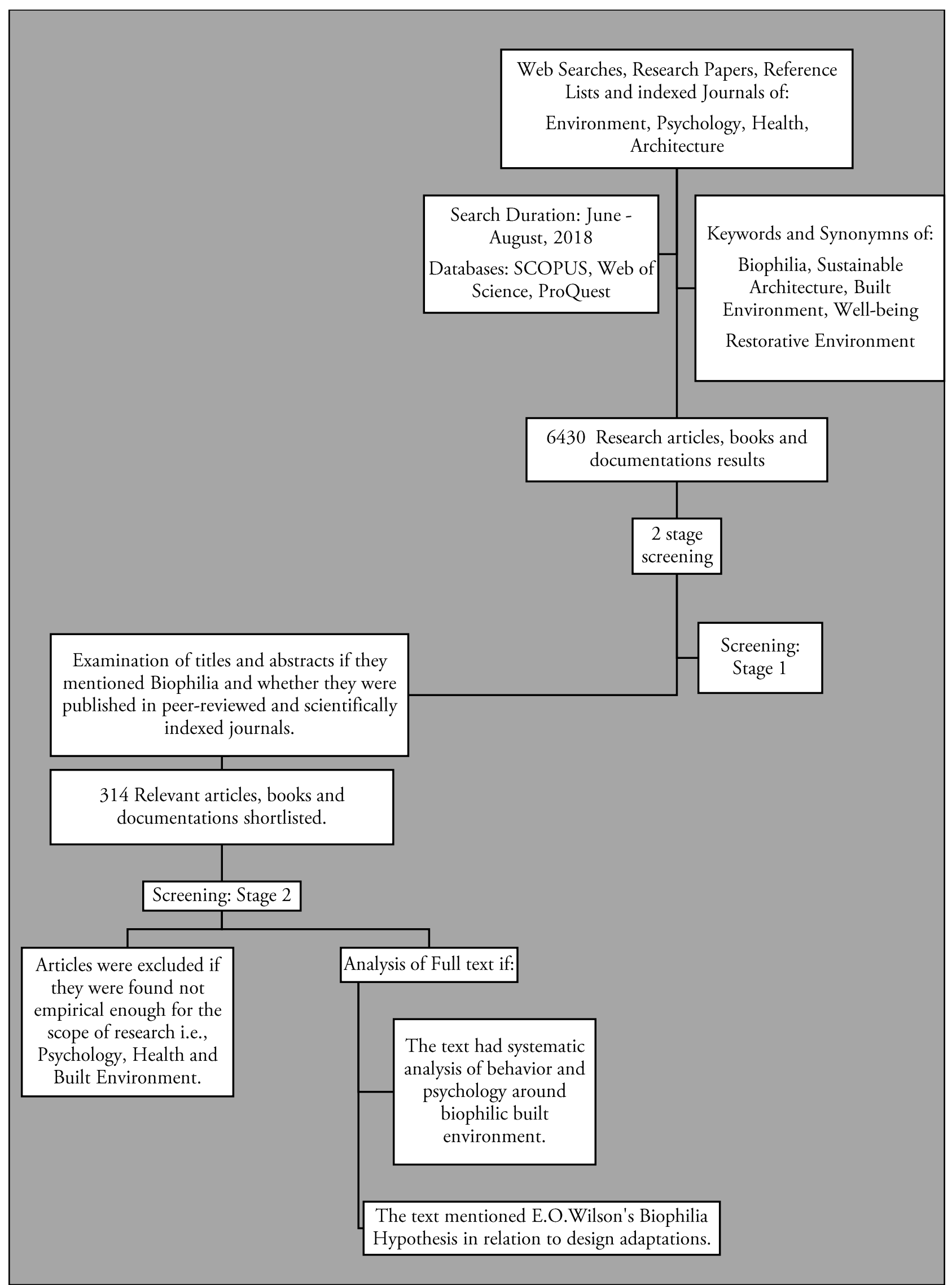

Fig. 1. Graphical Methodology: Literature search and article selection. 


\section{BIOPHILIA and BIOPHILIC DESIGN}

The term 'Biophilia' was first mentioned in the works of German psychologist Fromm (1973), as "the passionate love of life and of all that is alive". The term has ancient Greek origins (bios: life, philia: love) and was later popularized by American Biologist Wilson (1984). In the hypothesis, biophilia is defined as "the urge to affiliate with other forms of life" (Kellert and Wilson, 1995). The human evolution has observed that $99 \%$ living species had an adaptive response towards natural environment and its subsequent forces (Kellert and Calabrese, 2015). These adaptive responses led to prolonged human reliance on nature and its resources. Biophilic design is the multidisciplinary transformation of biophilia into the design prospects of built environment (Kellert et al., 2011).

Table 1. Biophilia definitions and adaptations

Reference Definition

Fromm (1973)

The passionate love of life and of all that is alive.

Wilson (1984)

Our innate tendency to focus upon life and life-like forms and, in some instances, to affiliate with them emotionally.

Kahn (1997)

A fundamental, genetically based, human need and propensity to affiliate with life and lifelike processes

The evolution of Humans as a species from Homo sapiens' migration out of Africa until the invention of electricity has been seen as a bio-centric development of physique, mind and senses (Kellert and Calabrese, 2015). Architect and design theorist Christopher Alexander (1977) has expressed in his book 'The Pattern Language' that a number of natural patterns here are 
quintessential for humans, they are so deeply inbuilt within the human nature now and they are going to be there within them for next 500 years as well. According to a study conducted in Sweden by psychologist Ohman and Mineka (2001), humans as a species have hereditary behavioural inclination towards natural forces, their stimuli responses swing between constructive and destructive in terms of emotions. The available research in this domain considers four aspects of the natural world (Fig.1): animals, plants, landscapes, and wilderness (Frumkin, 2001). The concept of Biophilia strengthen the premise that the built environments need to be equipped with both biotic and abiotic features for psychological well-being as well as for preservation of natural environment (Downtown et al., 2017).

Biophilic design counts on the conceptualization of the theory of biophilia under the pretext of architecture, urban design, landscape design and sustainability. Kellert and Finnegan (2012) in their bio-centred documentary 'Biophilic Design: Architecture of Life' claimed, "Buildings and living spaces with biophilic design bring people closer to nature”.

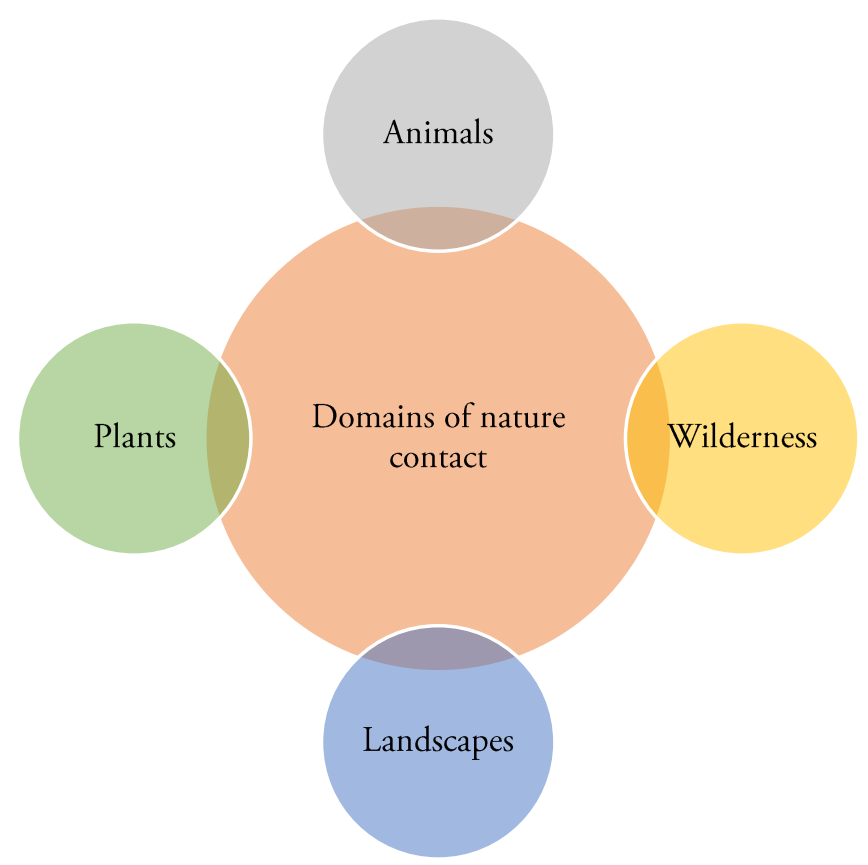

Fig. 2. Domains of Nature Contact adapted from Frumkin, 2001. 
Biophilic Design depends upon the following basic elements (Fig. 2): natural ventilation, natural lighting and organic forms (which exist naturally), and natural landscapes. These features strengthen the bond between humans and their immediate environment (Duzenli et al., 2017). Research conducted in this field shows that upcoming residences, schools, townships, hospitals and corporate offices have embarked to acknowledge the beneficiary aspects of Biophilic design.

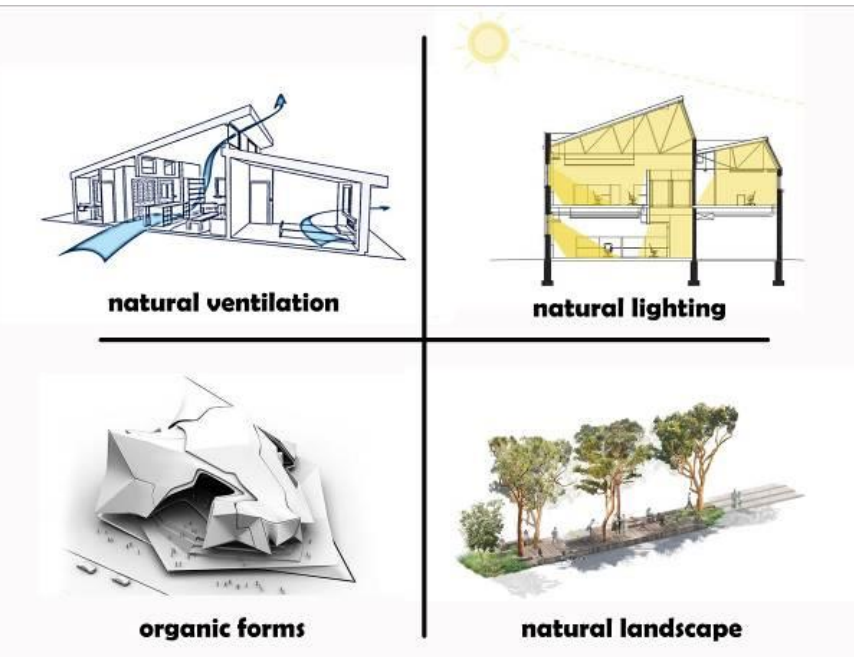

Fig. 3. Basic Elements of Biophilic Design adapted from Duzenli et al., 2015.

\section{WELL-BEING, STRESS and RESTORATION}

The Humans spend an average of $90 \%$ of their total time in vicinity of built environment. The mental health is affected by built environment in two ways (Fig. 3) i.e., Direct and indirect. Housing situations, crowded spaces, noise, indoor air quality, and ambient light are among the environments, which have direct mental health consequences. The mental health is indirectly affected by interferences in psychosocial processes by built environments (Evans, 2003). Psychosocial processes are reference to human psychological aspects such as wellbeing, commitment, engagement, self-efficacy, self-esteem, belongingness, motivation and 
satisfaction. Altering the psychosocial processes often, lead to mental disorders of varying degrees in which built environment may or may not be the cause of disorder and is rather seen as an enhancer (Carlson et al., 2012). Mental illness is considered a major psychological issue for the prisons of 21 st century, a variety of research concluded that around $89 \%$ prisoners face traits of depressive persona and $74 \%$ have experienced stress related issues (Soderlund and Newman, 2017).

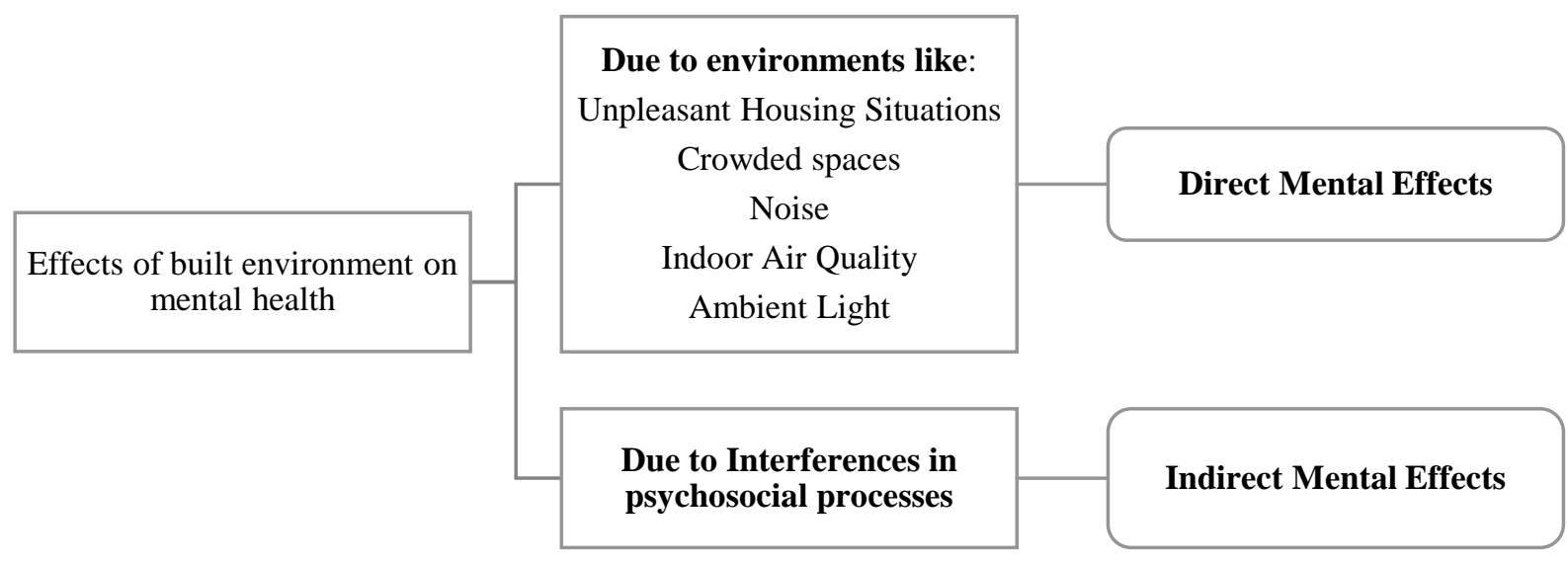

Fig. 4. Effects of built environment on mental health adapted from Evans, 2003.

Table 2. Direct Mental effects of built environment on human well-being.

\begin{tabular}{|l|r|}
\hline Deviation Contributors & Direct Mental Effects \\
\hline Temperature & Lowering the rate of performance and \\
(Chua et al., 2006; Fang et al., 2004; & productivity. \\
Kamaruzzaman and Sabrani, 2011; & Distraction \\
Seppanen, Fisk and Lei, 2006; & \\
Wargocki et al., 2006). & \\
\hline
\end{tabular}




\begin{tabular}{|l|r|}
\hline Ventilation & Lowering the rate of performance and \\
(Bakó-Biró et al., 2012; Seppanen, & productivity. \\
Fisk and Lei, 2006; Fisk, Black \& & Negative effect on memory and concentration. \\
Brunner, 2012). & Disturbed circadian rhythm. \\
\hline $\begin{array}{l}\text { Illuminance } \\
\text { Schlangen, 2007; Osterhaus, 2005). }\end{array}$ & Lowering the rate of performance and \\
\hline $\begin{array}{l}\text { Noise } \\
\text { (Takki et al. 2011; Seidman and }\end{array}$ & Behavioral and physiological effects. \\
Standring 2010). & Distraction \\
\hline air Quality & Tiredness. \\
\hline
\end{tabular}

According to a study conducted on 'Built environment and mental health', attractive internal environments which depend on use of plants lead to lower perception of stress and helps in creating a restorative environment (Renalds et al., 2010). Multiple studies have proposed that confrontation with nature reduces the chances of heart related diseases and abnormal pulse rates, maintains a healthy blood pressure, diminishes the production of cortisol and enhances parasympathetic nervous system functions, which directly relates to internal organs and glands (Song et al., 2016). 
Humans react positively not only towards head-on exposure to natural environment but also they have responded with certainty to artificial imitation of nature and its forms in fractal patterns, and also to cases of organic and conceptual mimicry of the natural entities (Appleton, 1996). For example, Kulper and Roy (2005) attempted to link architecture with biophilia through the design of an 'Institute for Nano biomedical Technology and Membrane Biology' in China. They imitated the design of a cell for the exterior of the building and the interior mimics the molecular biology (El-Zeiny, 2012). Another example of this are the Treepods installed for Shift Boston's 'Urban Intervention Contest'. The Treepods mimic the concept of trees and utilizes it as an air cleaning system that traps $\mathrm{CO}_{2}$. Since, it is based on the design of Dragon tree; it has wider foliage and is preferred by locals for shade (Rao, 2014).

Diette (2003) concluded in his study on effects of natural elements such as sound and sight on the people with Flexible Bronchoscopya that use of murals inspired by nature and natural sounds help in minimizing the degree of pain they experience. A study conducted by Lohr and Pearson Mims (2006) reinforced the hypothesis that the presence of indoor plants in an uncomfortable or stressful environment induces the pain tolerance of the occupants. Lohr and Pearson had previously conducted a similar study for a window-less work environment and found that occupants exhibited less stress, had more productive thoughts, and had more presence of mind when natural plants were used in the room interior in comparison to the data collected for the same room without the indoor plants (Lohr et al., 1996).

An analysis of the selected available literature was conducted and the data was categorised accordingly based on their impact on the associated and relevant patterns of biophilic design. Certain benefits of biophilic design have been enlisted in Table 3. along with the applied strategies used to attain them. The degree of benefits include mood enhancement, sense of 
defence against outdoor environment, satisfactions of thermoreceptors of the body, cognitive improvement, stress management, constructive problem solving skills, improvement of short term memory and enhanced creativity.

Table 3. Benefits of Biophilic Design for Human well-being

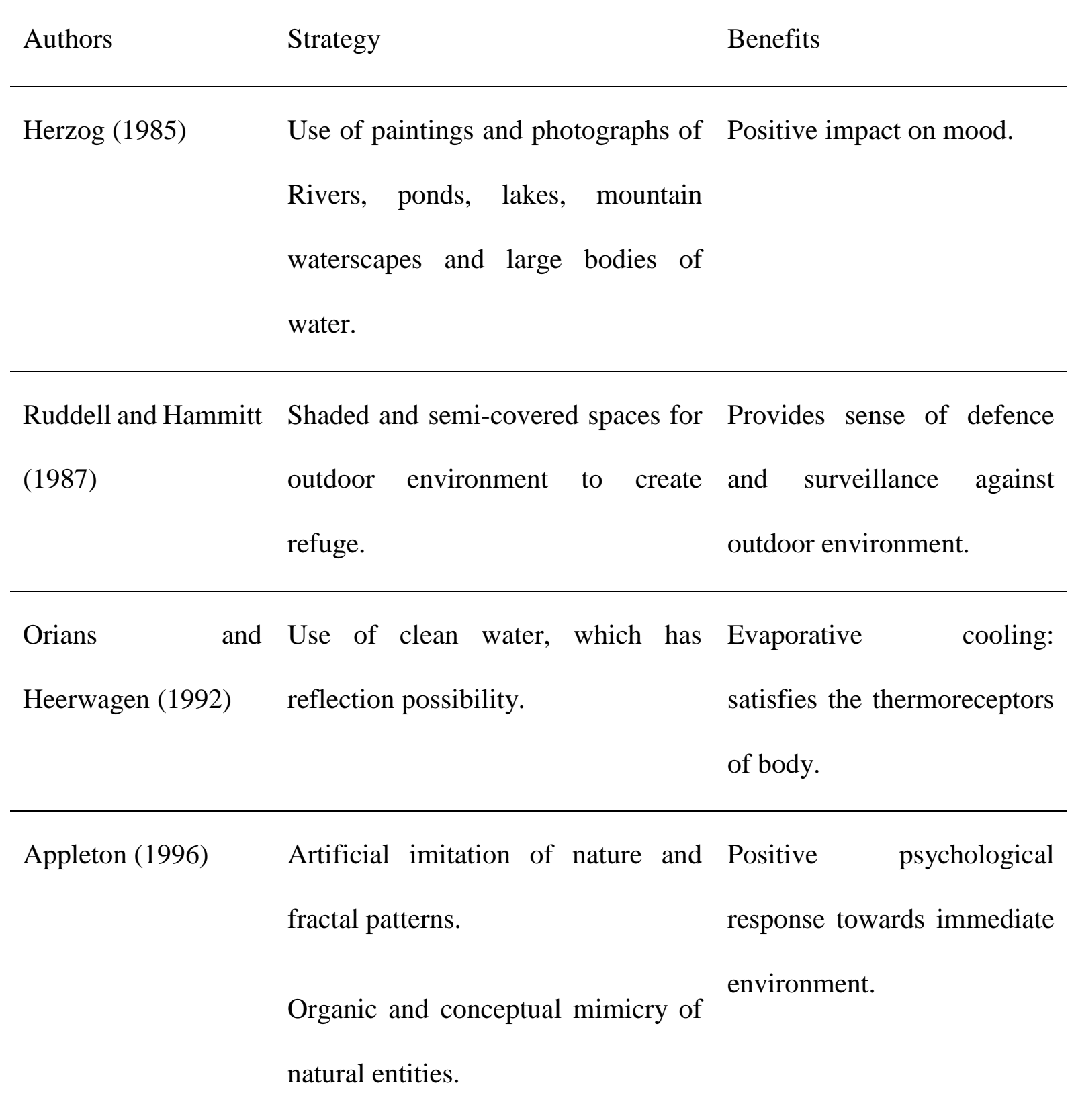


Lohr et al. (1996) Use of plants in windowless indoor Pain tolerance and stress

Lohr and Pearson environment. management.

Mims (2006)

Increased productivity and enhanced presence of mind.

Rapee (1997) Introducing levels of risk and control Enhances problem solving in design. and decision making skills.

Edwards and Modified daylight mechanism, which Artificially generated mood Torcellini (2002) can adjust throughout the day. and creativity enhancer for workplaces and habitats.

Van den berg et al. Natural movement of water. Stress reduction. (2003)

Diette (2003) Use of natural sounds and murals Reduction in degree of pain inspired by nature. experienced by patients of flexible bronchoscopya.

Ikemi (2005) Creation of mystery through Enhanced preference of arrangement of tress and objects. $\quad$ space or facade in case of housing.

Leslie (2008) Design of open and unrestricted Provides sense of security to

Friedman (2017) spaces to represent prospect. the occupants. 
Renalds et al. (2010) Use of plants in internal Lower perception of stress. environments.

White et al. (2010) Increasing proportion of visible Increases preference of the aquatic space. $\quad$ space.

Alvarsson et al. Small or momentary interventions Positive health impacts. with non-visual senses. Physiological and psychological relief.

Almusaed (2010) Presence of natural or transparent Positive psychological effect, light. $\quad$ flow of positive emotions and enhances creativity.

Mehta el al. (2012) Natural sounds of birds, winds and Enhanced creativity. gushing of leaves.

Tsunetsugu et al. Visual connection with nature for $5-$ Stress reduction. 20 minutes.

Van Wieren and Elements with unprecedented Acts as natural modulators of Kellert (2013) organic growth like planters and fear and surprise for the shrubs. pedestrian. 
Browning et al. Good connection with ongoing Relaxation, nostalgia, natural processes and systems.

enlightenment and repeated

Biomorphic designs and patterns anticipation. Minimises stress and creates visually preferred environments.

Ryan (2015)

Clouds, shadows, natural sounds and Generates interest and acts as water reflections. natural energiser.

Song et al. (2016) Confronting natural environments. Reduces chance of heart diseases, balances pulse rate and blood pressure, reduces secretion of cortisol and enhances parasympathetic nervous system.

Sharifi and Appropriate task specific lux levels

Improves the accuracy of Sabernejad (2016) of light. senses and induces the power of vision.

Lee and Park (2018) Including accessible hideout spaces Psychological stability: in library design, which can provide tranquillity and safety in an a view of natural systems. unfamiliar environment.

Yin et al. (2018) Short exposure to biophilic indoor Lower systolic and diastolic environment. blood pressure and skin 


conductance. $14 \%$
improvement in short term
memory.

Biophilic design has constructive impacts on the human psychology, physiology and immediate surrounding environment. The benefits enlisted in Table 4 strengthens the postulates of Wilson's Biophilia hypothesis. The studies conducted by Ryan et al. (2014) and Cramer \& Browning (2008) have strengthened the premise of biophilic design and argued that biophilia in design helps in improving the overall health of the occupants and works positively for their levels of satisfaction, quality of performance and productivity.

\section{PATTERNS OF BIOPHILIC DESIGN}

There have been a number of significant attempts to categorize and relate various variables and attributes of biophilic design to have a confined idea of an actual hypothesis for biophilia in architecture and in its associated disciplines. The most acknowledged versions of this are by Kellert and Wilson (1995), Soderlund and Newman (2017) and Browning (2014).

Table 4. 'Evolution of 14 Patterns of Biophilic Design'

\section{Common Features of Biophilic}

14 Patterns (Browning et al., 2014)

\section{Design}

(Kellert, 2004)

\begin{tabular}{l|lc}
\hline 1. Natural lighting & $\begin{array}{ll}\text { Nature in the } & \text { Visual Connection } \\
\text { Space } & \text { with Nature }\end{array}$ \\
\end{tabular}


2. Natural Ventilation

3. Natural Materials

4. Natural and Indigenous Vegetation

5. Ecological Landscape Design

6. Open Space

7. Water views and Vistas of Nature

8. Shapes and forms that mimic organic forms

9. Vistas characterized by refuge and prospect

10. Natural features that evoke mystery

11. Exploration and Enticement

12. Natural features characterized by order and complexity

13. Natural Rhythms

14. Natural processes and change

15. Aesthetic and recreational values of nature
2. Non - Visual

Connection with

Nature

3. Non - Rhythmic

Sensory Stimuli

4. Thermal and Airflow

Variability

5. Presence of Water

6. Dynamic and Diffuse

Light

7. Connection with Natural Systems

\begin{tabular}{ll} 
Natural & 8. Biomorphic forms \\
Analogues & and patterns \\
& 9. Material connection \\
& with Nature \\
& 10. Complexity and \\
& Order \\
\hline Spature of the & 11. Prospect \\
& 12. Refuge \\
& 13. Mystery \\
& 14. Risk / Peril
\end{tabular}


16. Informational and intellectual values of nature

17. Emotional and Spiritual values of nature

Ryan and Browning (2014) in a nascent effort to gather evidence for different aspects of biophilic design proposed ' 14 patterns' and justified the use of term 'pattern' for three reasons:

- To propose a clear and standardized terminology for biophilic design;

- To avoid confusion with multiple terms already in use like metric, attribute, condition, characteristic, typology, etc.;

- To maximize accessibility for designers and planners by upholding familiar terminology.

\section{Visual connection with nature}

Visual connection with nature is observed as an important aspect of biophilia as it deals with several elements of visual comfort and relaxation. An example of this can be found at Myst (Fig. 5), which is initially designed as a biophilic housing project in hilly region of Kasauli, India. Each residential unit has unobstructed views of nature in order to regulate and maximise functioning of occupants and to enhance their creativity. 

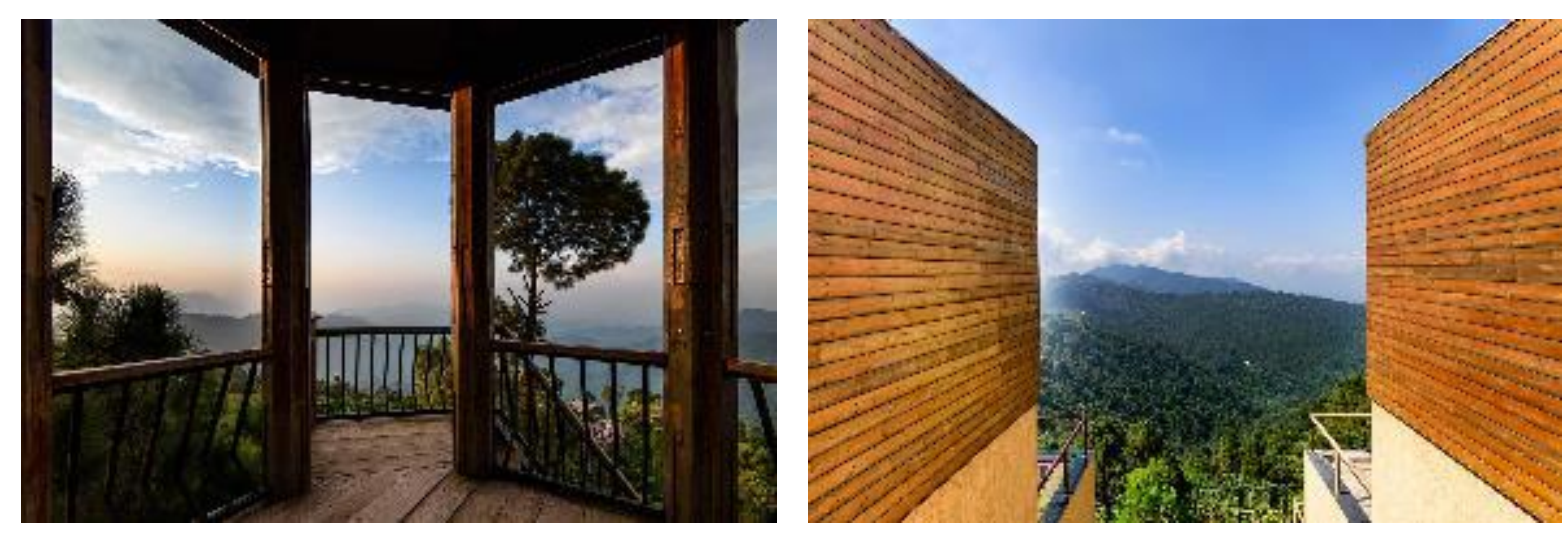

Fig. 5. Visual Connection with Nature at Myst, Kasauli by Tata Housing (Source: Myst Brochure)

It is also one of the most evident ones when it comes to identifying emerging design parameters:

- Stress reduction through visual connections with natural elements (Ryan et al., 2014; Van den berg et al., 2003). It also alleviates mood and enhances self-esteem (Biederman and Vessel, 2006; Fuller et al., 2007).

- Give priority to real natural elements instead of artificially produced or acquired aspects of nature (Kahn et al., 2008).

- Prioritizing the promotion of biodiversity over expansion of land (Fuller et al., 2007).

- Giving priority to spaces for exercise and recreation, which have visual connection with green spaces (Barton and Pretty, 2010).

- Minimum exposure to nature for 5-20 minutes / day (Tsunetsugu et al., 2013). 


\section{Non-visual connection with nature}

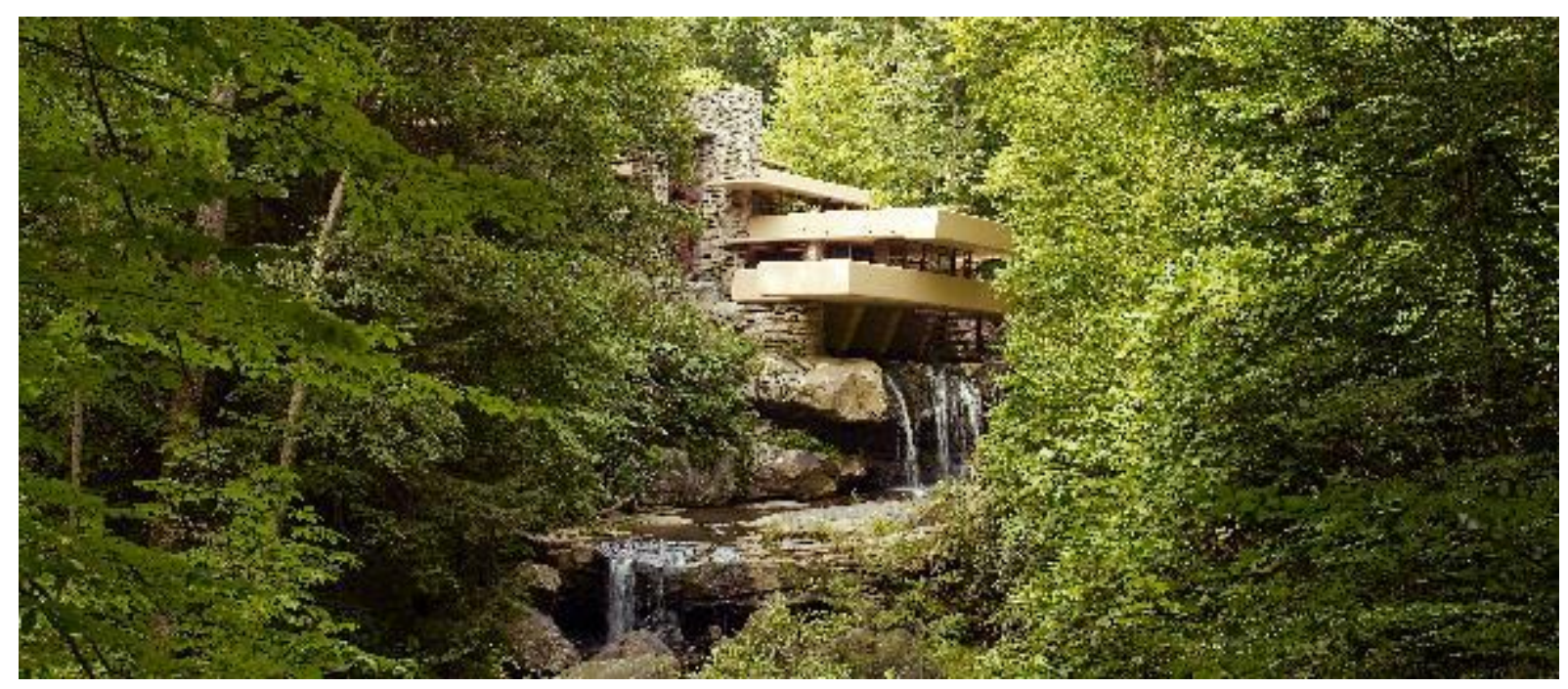

Fig. 6. The Fallingwater by Architect F.L. Wright in Pennsylvania (Source: Wikipedia Commons)

Non-visual connection with nature can be distinguished in the form of sensory receivers other than visual (eyes), such as auditory (sense of hearing), haptic (touch or kinaesthetic communication), olfactory (sense of smell), or gustatory (taste) that create a positive response to natural elements. F.L. Wright's organic architecture marvel 'The Fallingwater' (Fig. 6) depicts non-visual connection with nature where the sound created by the movement of water acts as a comforting and restorative element for the occupants.

From the activity and responses of above-mentioned sensory receivers, we can identify emerging design parameters as:

- Small or momentary interventions with non-visual sensory stimuli can have a positive health impact (Alvarsson et al., 2010).

- Giving priority to natural sounds over unpleasant urban sounds to generate physiological and psychological relief (Alvarsson et al., 2010). 
- Utilizing the natural sounds of birds, winds and gushing of leaves to enhance the creativity of the people (Mehta et al., 2012).

\section{Non-Rhythmic sensory stimuli}

According to Ryan, non-rhythmic sensory stimuli are random and transient connections with nature that can reduce stress and improve productivity. The non-rhythmic sensory stimuli can be listed as clouds, shadows, nature sounds, and water reflections. A space that has good nonrhythmic sensory stimuli acts as a refreshing environment; centralizes human interest and functions as a natural energizer (Ryan, 2015). Fig. 7 depicts the implementation of elements of non-rhythmic sensory stimuli in active designs of Shimla Wildflower Hall and The Oberoi Amarvillas, Agra.

Emerging design parameters for non-rhythmic sensory stimuli can be identified as below:

- A cast shadow can be utilised to reveal features of the 3 dimensional form that are not usually apparent in a direct view of the object hence emphasising the space (Tregenza \& Loe, 2013).

- The clouds can be treated as restorative mediums due to their non-rhythmic nature and can be utilised through horizontal or diagonal openings in the roof or wall to make creative use of their view from interior spaces (DeKay \& Brown, 2013). 

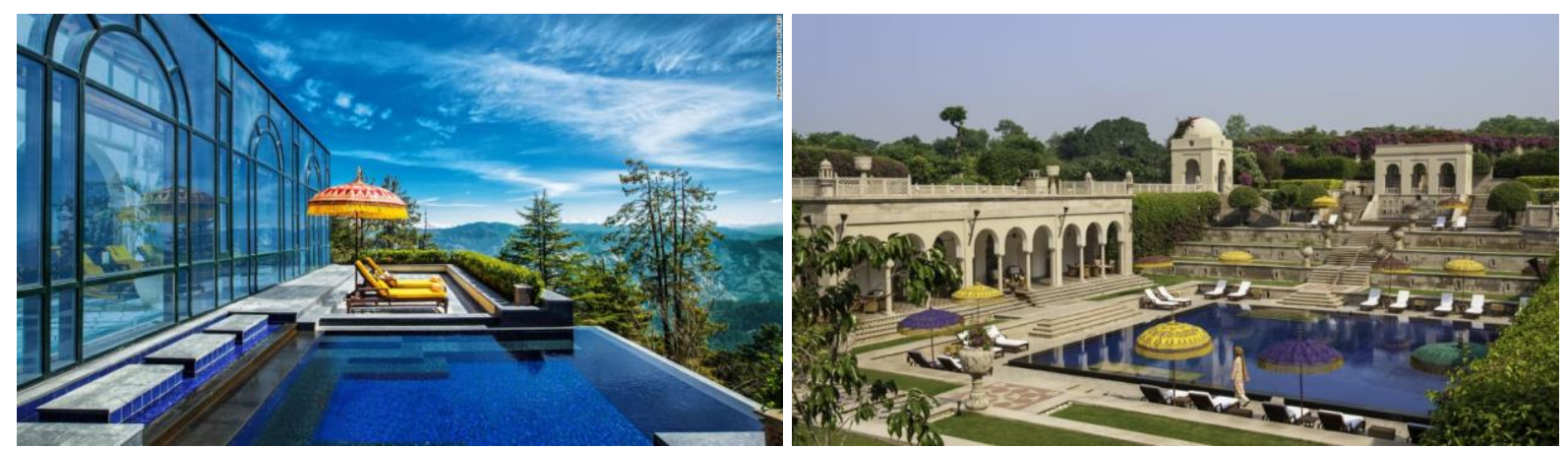

Fig. 7. Non-Rhythmic sensory stimuli: Clouds, shadows and reflections as part of built environment at Shimla Wildflower Hall (left) and The Oberoi Amavillas, Agra (right).

\section{Thermal and Airflow variability}

The role of ventilation and thermal comfort is very crucial in the satisfaction index of human habitats. Airflow, thermal diversity and natural ventilation are some key factors that provide thermal comfort to the occupants of buildings. Fig. 8 features the thermal comfort zones within the bioclimatic charts as put forward by Olgay et al. (1963) and Givoni (1992). Olgay’s chart uses $21^{\circ} \mathrm{C}$ (dry bulb temperature) as threshold for sunlight, moisture and winds required in order to obtain thermal comfort where as Givoni's version of bioclimatic chart advocated for a thermal comfort range of $20^{\circ} \mathrm{C}-28.5^{\circ} \mathrm{C}$ along with a $10 \%-90 \%$ range for relative humidity. According to ASHRAE (2013), for human thermal comfort the average humidity should range between $30 \%$ to $65 \%$ and the average temperature should range between $22.8^{\circ} \mathrm{C}$ to $26.1^{\circ} \mathrm{C}$ in summers and $20^{\circ} \mathrm{C}$ to $23.6^{\circ} \mathrm{C}$ in winters. 

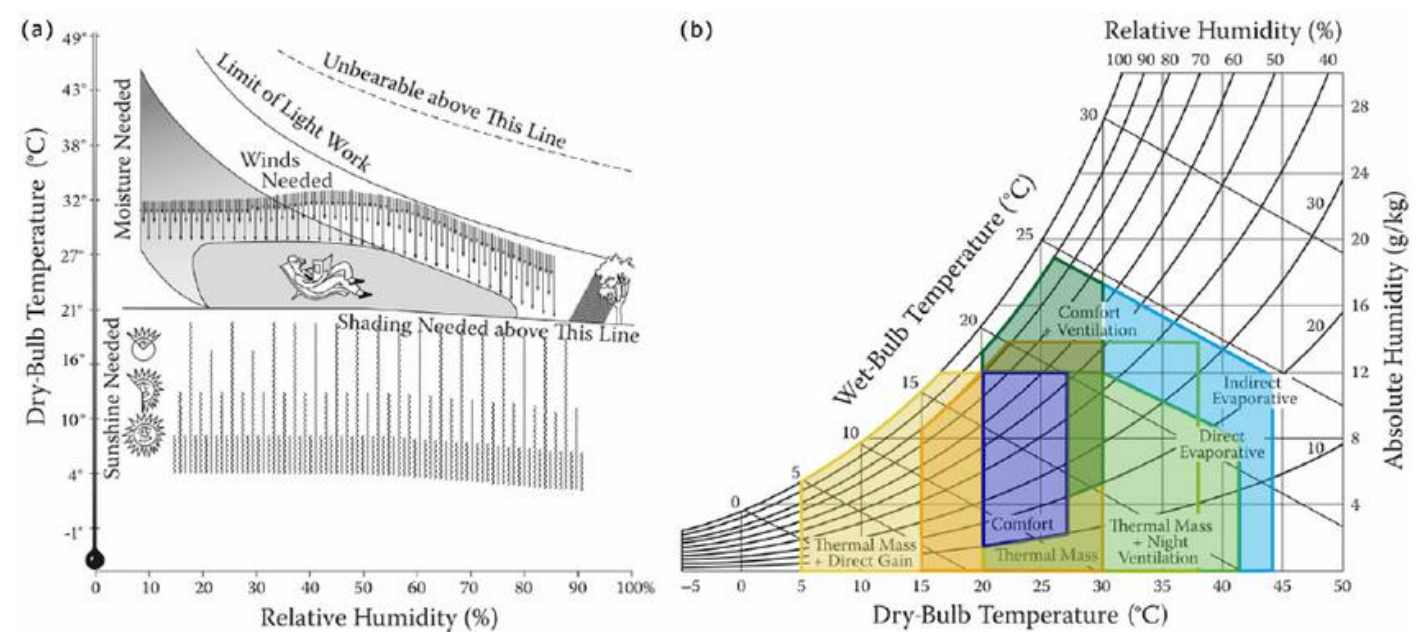

Fig. 8. Thermal comfort zones a) Bioclimatic chart (Olgyay et al, 1963). b) Building bioclimatic chart (Givoni, 1992).

The current population growth have put a significant pressure on the resources of renewable energies as well as on the ones provided by fossil fuels. To minimize the impacts of this on the energy, adequate ventilation and regulation of heat sources is recommended for buildings (Sharifi and Sabernejad, 2016).

Emerging design parameters for a balanced thermal environment and air-flow:

- Maintaining low and dense vegetation between the buildings especially where high temperatures are measured (Gaitani, Mihalakakou \& Santamouris, 2007).

- Maintaining a small water body to induce evaporative cooling for the surroundings (Givoni, 1992).

- Pergolas used with deciduous plants and trees provide solar control and provide a shade induced cooling in summers (Sandifer, 2009; Alexandri \& Jones, 2006).

- Employing green roofs and green walls for reduction in heat gain and for maintaining a fresh air flow (Alexandri \& Jones, 2006). 
- Construction materials of high emissivity and reflectivity values to be used in order to avoid excessive heating in summers (Gaitani, Mihalakakou \& Santamouris, 2007; Santamouris, Synnefa \& Karlessi, 2011).

\section{Presence of water}

The presence of water in biophilic architecture is considered a restorative environment both in visual as well as auditory aspects (Ulrich et al., 1991; Alvarsson et al., 2010). The quality of water decides the degree of human preference towards it for restorative environments, i.e., dirty water will be less restorative than clean water (White et al., 2010). Other than its psychological benefits, water has climate responsive capabilities as it helps in bringing down the rising temperatures through evaporative cooling and induces comfort through satisfying the thermoreceptors. St. Fiachra's garden in Ireland (Fig.9) designed by landscape architect Martin Hallinan, carries restorative and recreational properties as it depicts water in its positive aspects.

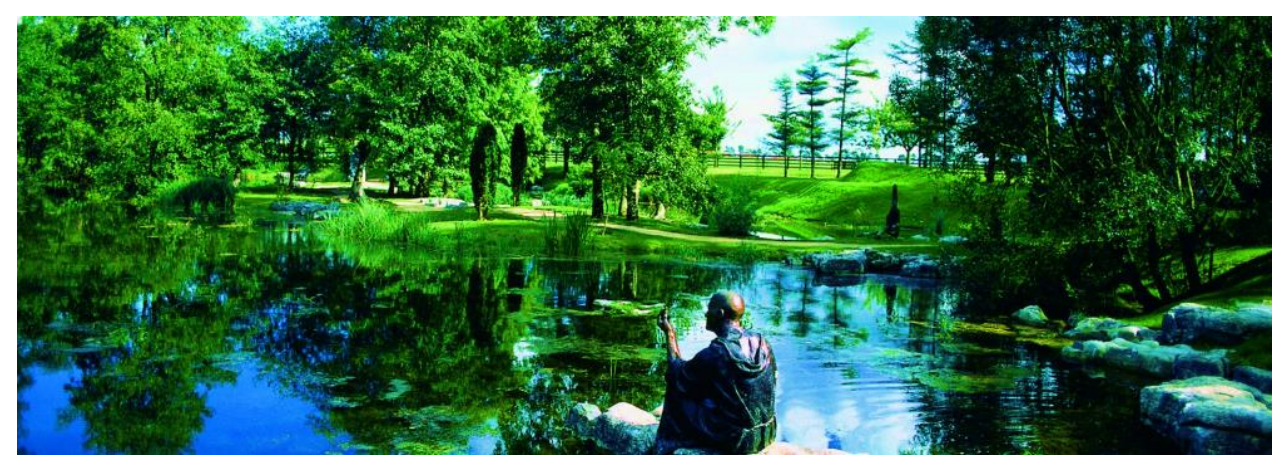

Fig. 9. St. Fiachra's Garden, Ireland by Architect Martin Hallinan (Source: Irish National Stud and Gardens).

Emerging parameters for water in biophilic design:

- The perception of water should be as a clean element (Orians and Heerwagen, 1992). 
- Priority should be given to an experience that involves use of multiple senses for water (Alvarsson et al., 2010).

- Priority should be given to natural movements of water, which are unpredictable (Van den Berg et al., 2003).

\section{Dynamic and Diffuse Light}

Light is associated with human psychology for visual comfort and has different results for a variety of exposures to it. Research suggests that the presence of natural and transparent light induces a positive psychological effect on the senses of occupant and if the source of light is sun then it enhances a vital locomotion movement, this further promotes flow of positive emotions and results in creativity (Almusaed, 2010). Appropriate lighting of a space promotes the accuracy of senses and induces the power of the vision (Sharifi and Sabernejad, 2016).

Emerging design parameters for balanced dynamic and diffused lighting:

- Transitional balance between indoor and outdoor spaces in terms of separation, privacy and zoning can just be induced through dynamic lighting conditions without the presence of any physical medium to act as a separator (Kelly, 1952).

- A modified daylight lighting mechanism, which has the capability to change throughout the day to mimic the features of natural light, such as circadian rhythm based lighting system, can pave a way for artificially generated mood and creativity enhancer systems for workplaces and habitats (Brawley, 2009). 
- Indirect exposure to ambient light through perforations can be ensured, which enhances the preference of the space and makes the space appear larger. It also improves brain's cognitive function and gives positive psychological feedback (Ozdemir, 2010).
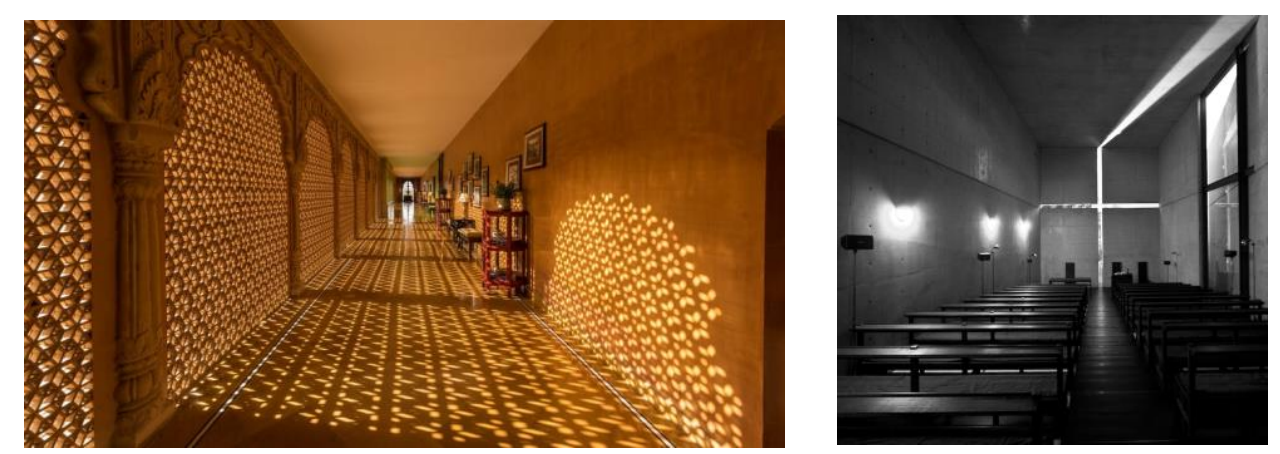

Fig. 10. a) Suryagarh (left) at Jaisalmer, India uses perforation (locally called Jali work) to aesthetically minimise the impact of direct light (Source: Suryagarh Jaisalmer). b) Church of Light, Japan (right) by Architect Tadao Ando uses light to amplify emotions for spiritual environment (Source: Tadao Ando Architect and Associates).

\section{Connection with Natural Systems}

Browning, Ryan and Clancy in their book '14 Patterns of Biophilic Design' have described connection with natural systems as "the awareness of natural processes, especially seasonal and temporal changes characteristics of a healthy ecosystem". Any space with a good connection with natural systems summons a bond to a greater whole that in turn improves the experience to provide relaxation, nostalgia, enlightenment and repeated anticipation (Browning et al., 2014). 

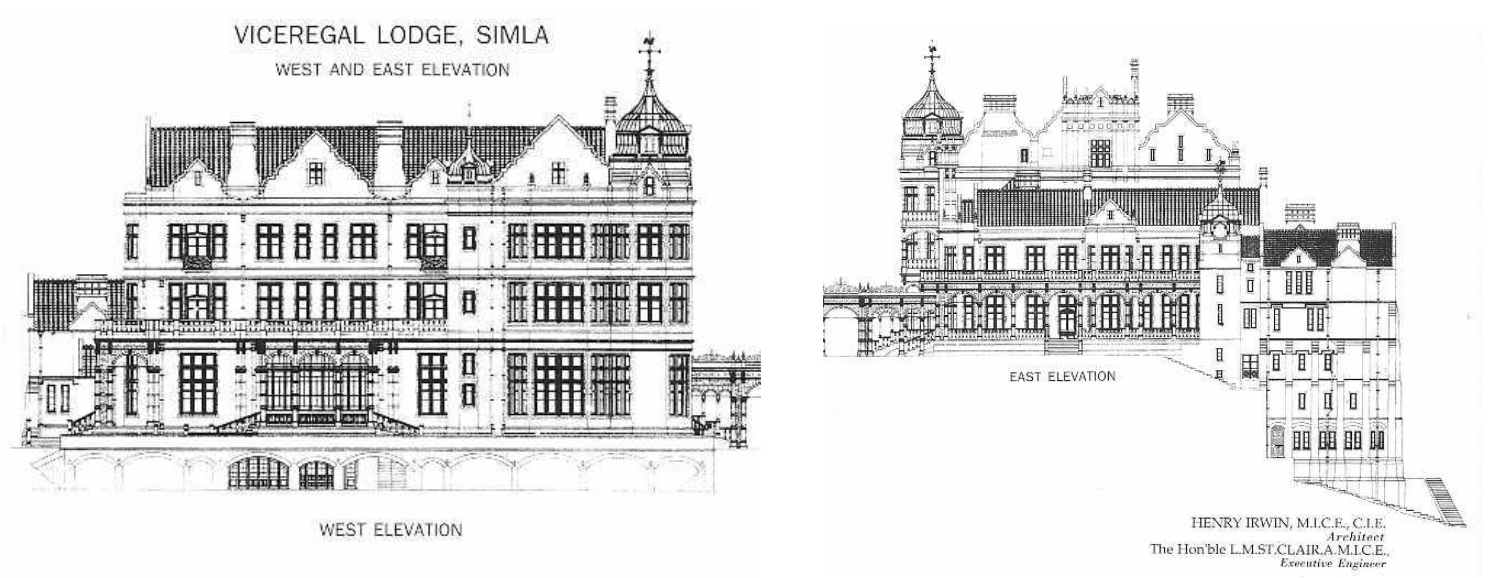

Fig. 11. Viceregal Lodge (Rashtrapati Niwas) in Shimla designed by Architect Henry Irwin. a) West Elevation (left) b) East Elevation (right) (Source: IIAS Archives)

The Viceregal Lodge was built in Jacobethan style by Architect Henry Irwin in 1888 as a summer retreat for the then Governor of British India - Lord Dufferin in Shimla. The entire complex was designed in accordance with the natural systems of the hilly region. In order to utilise the heavy rainfall the region receives, underground reservoirs were built below the landscaped gardens to accommodate rainwater for all the activities of the compound. Postindependence, the volume of water and capacity of tanks were extended to supply water to the neighbouring localities namely Tilak Nagar, Ghora Chowk and Hanuman Temple. New overhead tanks below the elevation line of the main building were constructed. According to Detailed Project Report (2009), the complex along with all the overhead tanks and underground reservoirs have a capacity of 0.23ML (Singh and Kandari, 2012). The way the Lodge (Fig. 11 \& Fig. 12) was set up against the slope of the hill gave it the ability to channelize and store water on lower levels and to interact with a variety of natural systems occurring around it. 

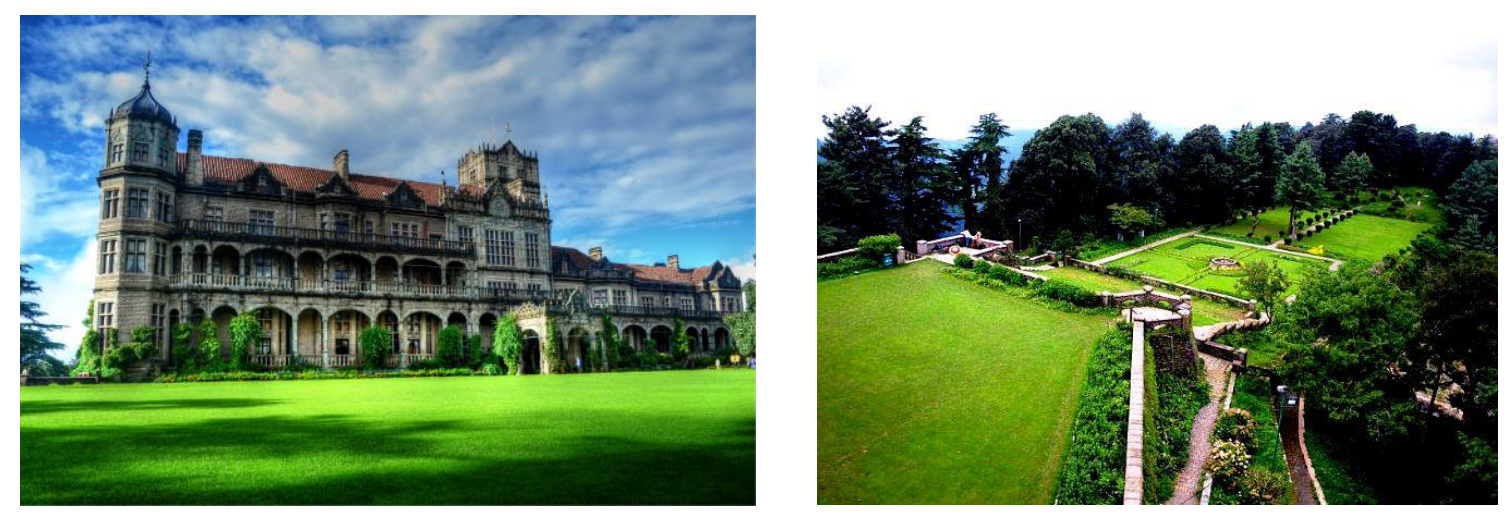

Fig. 12. The gardens and recreation courts of Viceregal Lodge, which are built above the underground reservoirs. (Source: Author)

Emerging design parameters to create quality connections with natural systems include:

- Collection, treatment and use of rainwater into the design of landscapes that is responsive to monsoon and channelizes surface run-off of water (Kinkade-Levario, 2007).

- The provision of visual access to naturally occurring systems is considered the easiest and smartest cost-effective approach. In other cases, the inclusion of design that has responsive tactics, robust structures, and adaptable land formations helps in achieving the desired levels of mobility for the design (Lin, de Dear \& Hwang, 2011).

\section{Biomorphic forms and patterns}

"Biomorphic forms and patterns are symbolic references to contoured, patterned, textured or numerical arrangements that persists in nature" (Browning et al., 2014). Biomorphic forms have been evident in a variety of artistic expressions, designs and structures since the evolution of civilization. Their presence can be marked in the ancient temples of Egypt, India and Rome and even in most modern designs of Spanish architect Santiago Calatrava (Hu et al., 2013). There 
has been an exponential reliance of architecture and design on the biomorphic forms due to its mathematical relevance in construction of various forms of buildings and the utilization of sanctum spaces as seen in temples of India, Greek and Rome through mimicking the natural elements with respect to the human body (Feuerstein, 2002).

Salingaros (2012) in his paper on 'Applications of the Golden Mean to Architecture' mentioned, "A crucial lesson that comes from understanding natural structure is to realize that scales in a natural hierarchy are skewed towards the smallest sizes. Natural growth begins at the infinitesimal scale and develops through an ordered hierarchy up to the largest size".
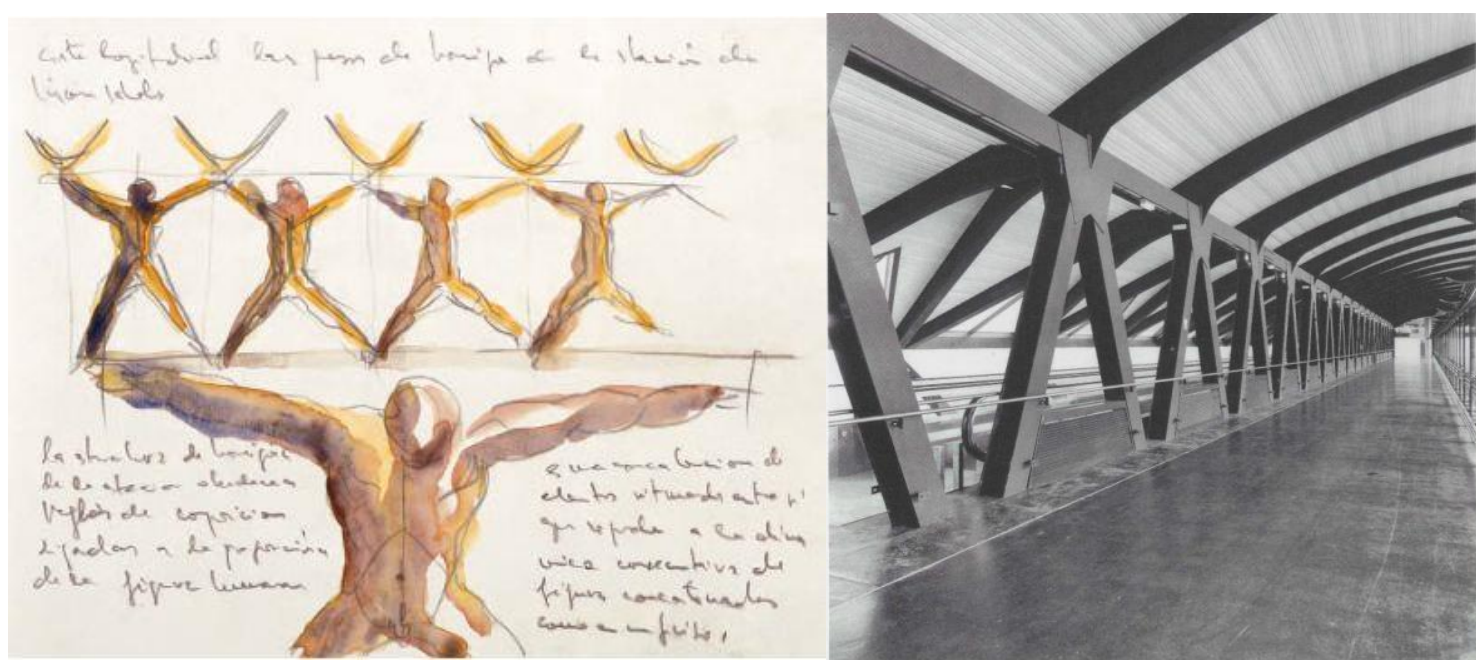

Fig. 13. Lyons Airport Railroad Station by Architect Santiago Calatrava. Concept design (left) and final output (right) (Source: McQuaid, 1993).

Biomorphic patterns help in creation of more visually preferred environments that are capable of enhancing cognitive performance of occupants through assistance in minimizing the stress (Browning et al., 2014).

Emerging design parameters to create qualitative biomorphic condition are: 
- The biomorphic attributes should be applied on 2 or 3 planes or dimensions (e.g., floor plane and wall; furniture windows and soffits) for greater diversity and frequency of exposure (Salingaros, 2012).

- As a design measure, try to avoid the overuse of forms and patterns that may lead to visual toxicity (Michl, 1995).

- More interventions that are comprehensive will be cost effective if they are introduced early in the design process (Browning et al., 2014).

\section{Material connection with Nature}

'Material Connection with Nature' pattern involves various physiological responses to a variety of elements of natural materials, and the influence of nature-based colour spectrum, of which the green colour exhibits features of improved cognitive conduct. Building materials that are derived from original natural materials are analogous to their 'natural' state (Browning et al., 2014). Architect Cesar Pelli recalled that as a student of architecture he learned that verite Modern architecture should depict no colour other than the colours of natural materials (Caivano, 2006). Architects and designers who belong to the purist regime of the profession consider whites, greys or anything else as superficial or unprincipled if they are not natural (Pelli, 1996).

USGBC's LEED gives extra weightage to the buildings, which efficiently adopt the sustainable and green materials with minimum or negligible impact on environment. The materials affect the cognitive user performance as well as reduce the energy consumption in some cases (Meisel, 2010). Pacheco-Torgal and Jalali (2011) in their research on use of vegetable fibres in cementing materials concluded that long bamboo fibres provide extended durability when used 
with cementing liquid. Apart from ecological and economic benefits, since bamboo is capable of representing the plant kingdom for a very longer duration of time due to its colour, it is preferred by designers to imitate a natural environment.

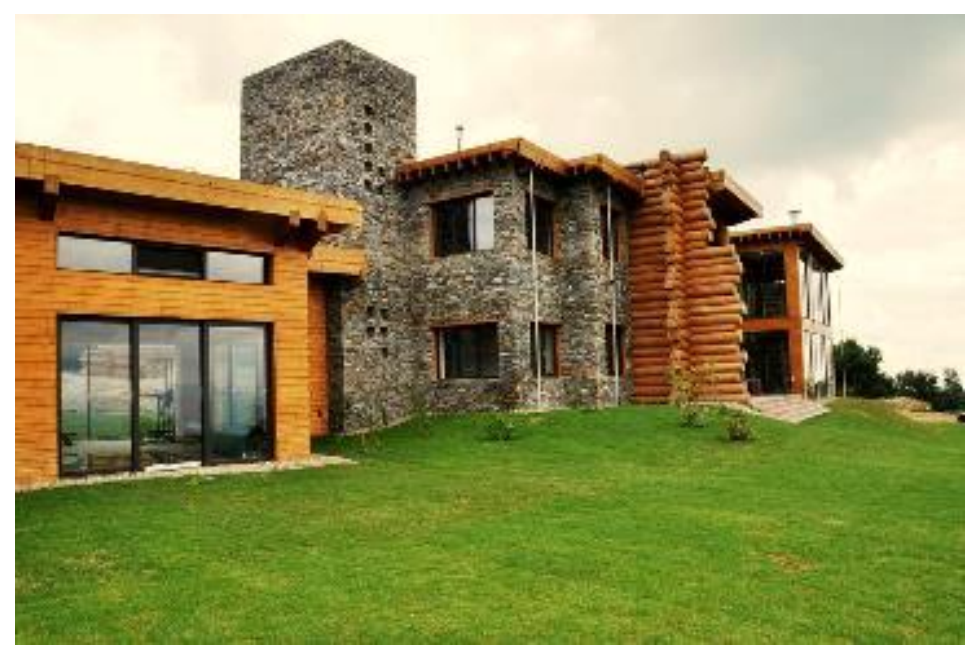

Fig. 14. Sustainable House, Romania uses natural materials for facades (Source: Tecto Architecture).

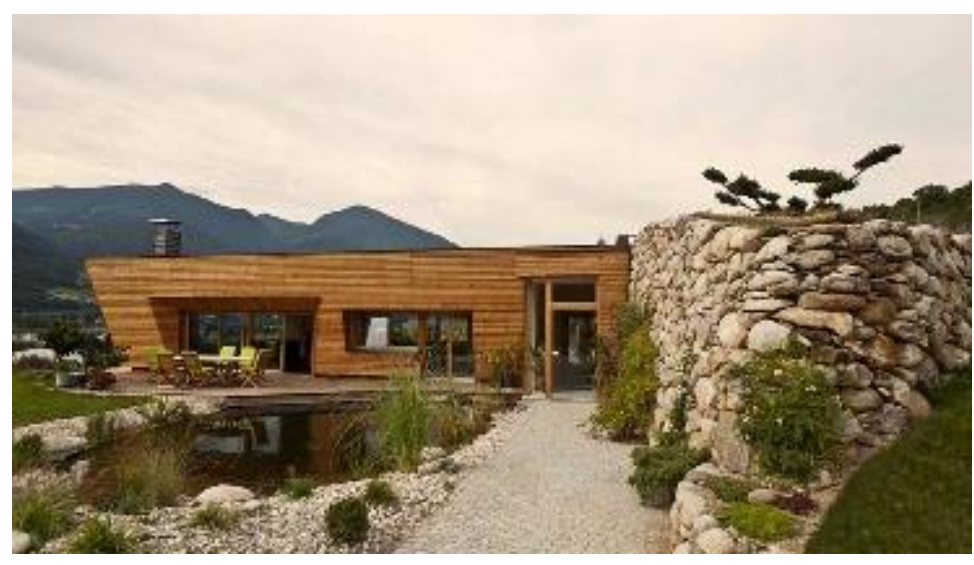

Fig. 15. Residence in Vahrn, Italy by Architect Norbert Dalsass uses natural materials in order to merge with the surrounding environment. (Source: Norbert Dalsass Architekt)

Emerging design parameters for creating a qualitative material connection with nature: 
- The frequency of use of a material in a space should be based upon its function (Addington \& Schodek, 2012)

- There should be a preference for natural materials over synthetically fabricated materials as human sensory receptors can identify and sense the difference between them (Ritter, 2007).

- The use of colours in a space should be done on an experimental basis. However, the green colour bears some favours of the designer due to its ability to enhance the mood of creativity in spaces (O’Connor, 2011; Minah, 2012; Dalke et al., 2006).

\section{Complexity and Order}

A space that exhibits information in the form of complexity is considered engaging for human mind. It creates an intrigue and is often considered as a regulator of balance between visually generated feelings of boredom and profuse. The main objective of this pattern is to create a visually productive environment that provokes a constructive cognitive response. Salingaros (2012) claimed that design bears a connection with natural growth through a structured hierarchy at various levels that can be found in a variety of natural structures. This structured establishment can however be complex and may appear to be ambiguous to users, this sense of complex nature relates to another biophilic pattern, i.e., mystery.

Rubinowicz (2000) explained in his paper on 'Chaos and geometric order in architecture and design' that these two are the basic components that constitute the structures of urban and architectural significance. They co-exist naturally and are interdependent. Geometric order is created through meticulous design and organised planning whereas chaos is generated when processes are self-organised. Architect Daniel Libeskind is known for creating a balance 
between geometrical order and chaos in his buildings while justifying intriguing feelings and emotions. Libeskind's renowned Royal Ontario Museum in Canada as well as Military History Museum (Fig. 16) in Germany are examples of organised complexity and order.

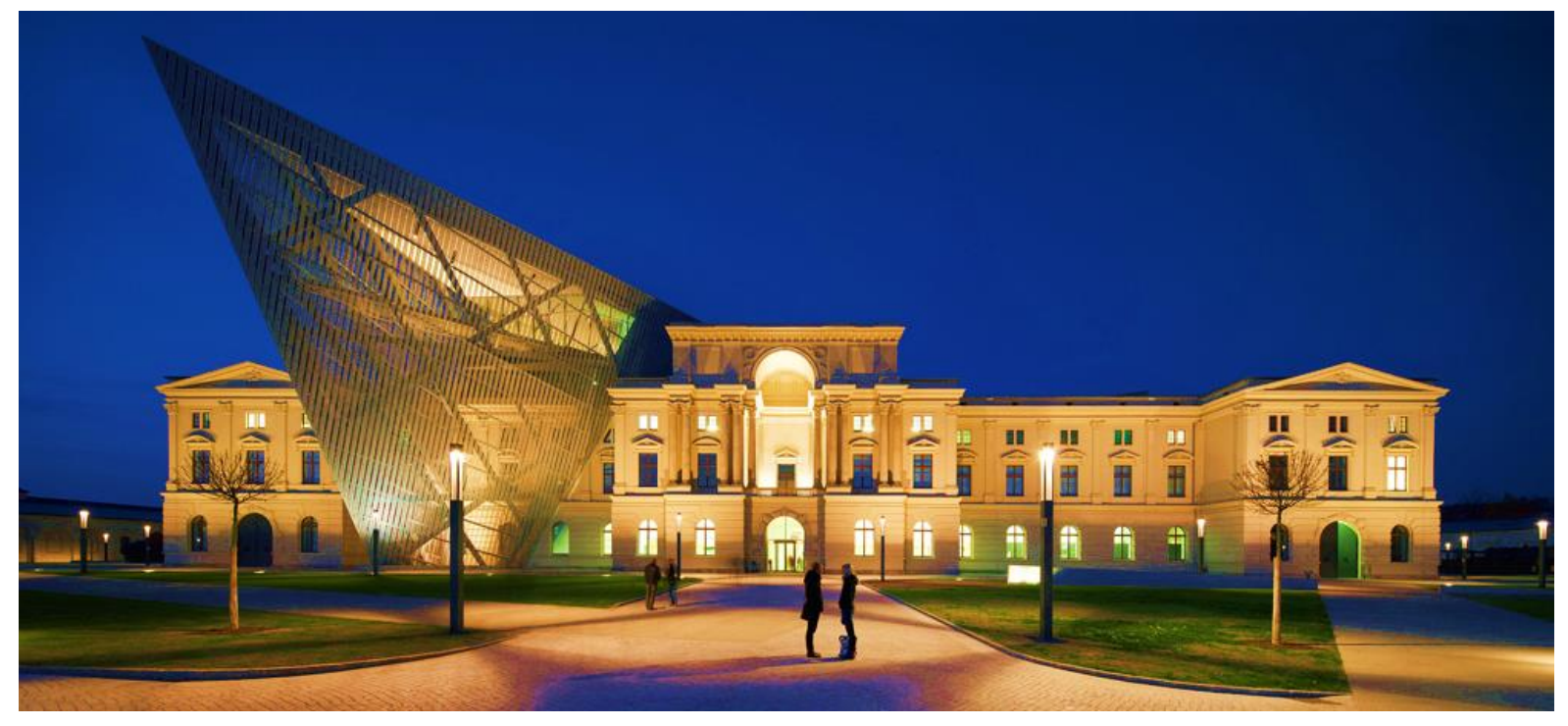

Fig. 16. Military History Museum, Germany by Architect Daniel Libeskind.

Fractal geometric patterns are a discrete result of repetition and a case of definite origins about which the entire evolution of form takes place (Kellert et al., 2011; Hagerhall et al., 2008). Understanding an already existing design is difficult and is not less than any challenge but creating a complex fractal pattern from origin is easy and repetitive in nature.

Emerging design parameters that can help in evolving a qualitative Complexity and Order based pattern:

- Give priority to fractal geometries while dealing with aspects of urban planning, architecture façades, landscape design, etc. (Browning et al., 2014). 
- To have greater impact of form in design, the fractal patterns with 3 iterations must be preferred over fractal patterns with 2 iterations (Kellert et al., 2011; Browning et al., 2014).

- The overuse of fractal patterns should be avoided to maintain a balance between stress reduction and restoration. The underuse of fractal patterns may lead to disinterest in design and offer predictability (Kellert and Calabrese, 2015; Browning et al., 2014).

- Buildings with fractal patterns as design elements in façade must consider the context and the impact on the city skyline (Browning et al., 2014; Joye, 2007).

\section{Prospect}

Prospect is defined as a pattern which provides an undisturbed, unrestricted, open and clear view over a large area or space for the purpose of monitoring, planning and surveillance. The idea of this is to provide the occupant a sense of freedom with an inherent sense of safety, security and control over their immediate environment that is not native to them (Browning et al., 2014). Hildebrand (1991) explained in his book 'The Wright space: pattern and meaning in Frank Lloyd Wright's houses' that for spaces in the building interiors or for spaces of high urban density, prospect is considered as the ability to observe one space through another. It builds up when there are certain divergence with the option to see through an alignment of multiple spaces. One of the best example of prospect is Kahn's Salk Institute in California. Its central courtyard establishes the argument of prospect within the premise of built environment through the deliverance of open and unrestricted spaces in it, while it strengthens the sense of security for the occupant (Friedman, 2017; Leslie, 2008). 

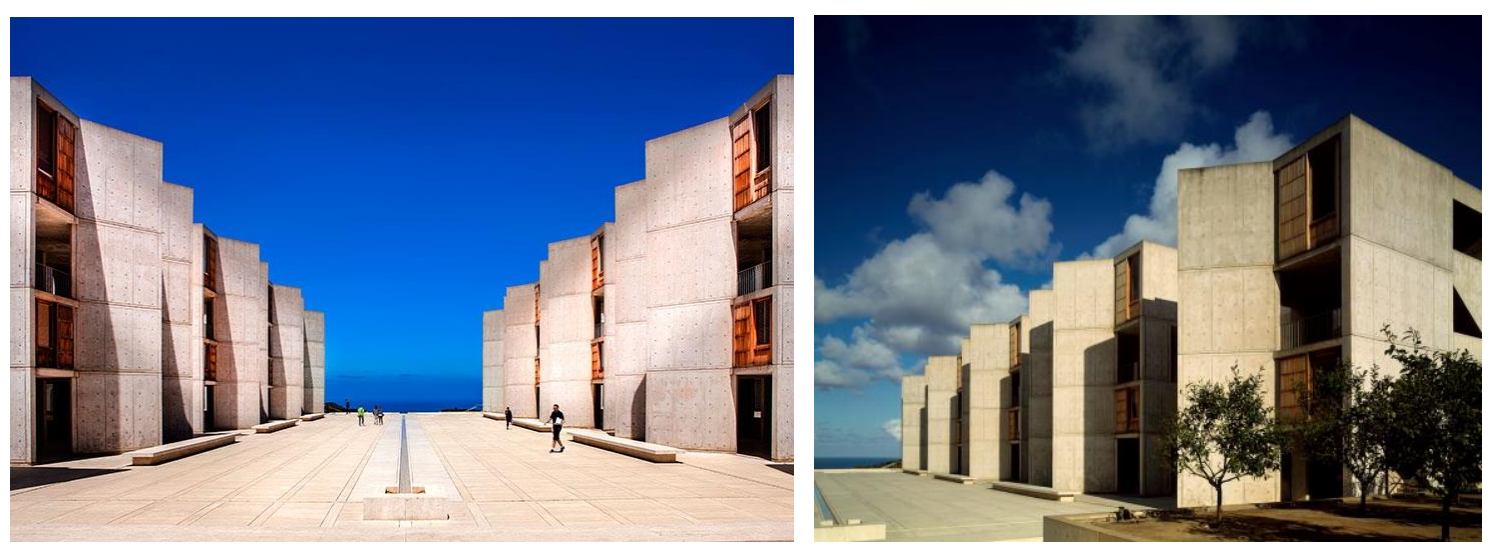

Fig. 17. Salk Institute for Biological Studies by Architect Louis Isadore Kahn in Sandiego,

California employs open space for the purpose of prospect. (Source: Sandiego Magazine)

Emerging design parameters that may help in creating a qualitative Prospect:

- Design interventions like placing stairwells at building edges with glass façade and internal glass walls can form a stable Prospect feature.

- Fenestrations that allow visual transparency along the corridors can make feature rich arrangements opportunities for workstations in office spaces (Ozdemir, 2010).

- A focal length range between 6 meters and 30 meters is preferred when there is adequate depth available for enhancing the experience of the user for walking, bicycling and similar exploratory in campus activities. This gives the user a control over their subconscious range of vision and enhances the preference of the space (Browning et al., 2014).

- Preference should be given to the quality of the symbiosis of Prospect and Refuge rather than the size or the repetition of the same feature (Joye, 2007).

- Visual Connection with Nature has the capability to optimize the Prospect experience with a quality view (Beatley, 2011). 


\section{Refuge}

According to Browning, Ryan and Clancy (2014), "Refuge is a place for withdrawal, from environmental conditions or the main flow of activity, in which the individual is protected from behind and overhead". A space which offers a good Refuge pattern should enhance the feelings of safety, offer a sense of 'katabasis' i.e., retreat or recoil, for stress relief, restoration and inducement of a work efficient environment for individuals or groups. Dosen and Ostwald (2013) explained that the theory of prospect and refuge is about being able to observe all your surroundings while being hidden and secure. This trait of human psychology is the reason why certain environments are preferable while in isolation like lighthouse, lake-house and ranches.

A qualitative Refuge space has the ability to appear unique and stand out from its native environment. It offers a meditative, protective and welcoming environment without creating any unnecessary disengagement for the occupant (Appleton, 1996). Hildebrand (1991) argues "the edge of a wood is one of the most prevalent of natural prospect-refuge conjunctions" because it offers defence against hostile forces like weather and predators, but enables occupant for extended outward surveillance.

According to Grahn and Stigsdotter (2010), the feedback for health in case of refuge is better than that of prospect. In addition to that, the symposium of both the patterns (prospect and refuge) delivers an elevated and enhanced result and establishes hope for further collaboration between these two for improvement of biophilic design. 

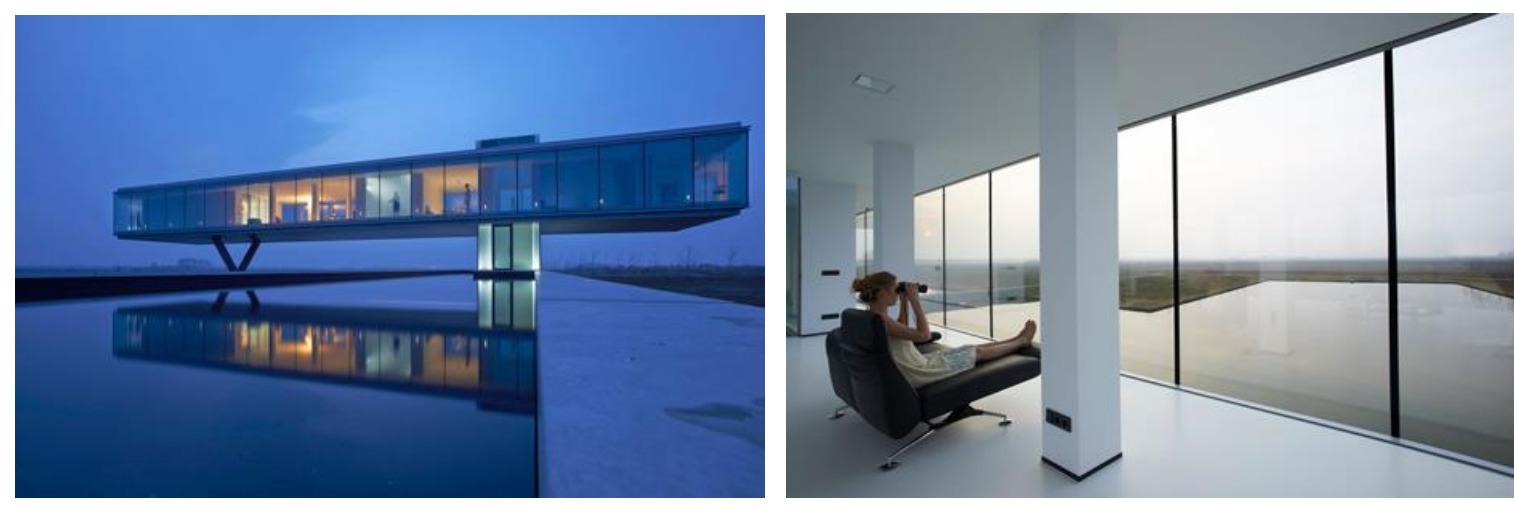

Fig. 18. Villa Kogelhof, Netherlands by Paul de Ruiter Architects exhibits the features of both prospect and refuge. (Source: Jeroen Musch, Dezeen Magazine)

Villa Kogelhof (Fig. 18) is an example of both prospect and refuge as the building sits in a desert landscape with open and unobstructed views on all ends. It is built in two sections: one of it is built underground giving the assurance of refuge in the isolated environment and the other is uplifted with minimalistic and obscuring supports separating it from the ground and whatever remains normal.

A study aimed at identifying the components of restoration in small urban parks concluded that the restoration capabilities of a park does not depend only on the size rather it includes the design and its components as well (Nordh, 2009). For large urban parks, users prefer refuge areas under large trees that offer shade and spaces around the vegetation surrounding a meadow (Ruddell and Hammitt, 1987).

Emerging design parameters to attain qualitative Refuge:

- Lower ceiling levels induce an effect of refuge within usual environments. Some architectural adaptations for refuge inside the built space are soffit, false-ceiling and suspended fabric (Browning et al, 2014; Dee, 2004) 
- A combination of refuge spaces should be used instead of a single one for buildings where a higher frequency of users are involved (Day, 2017).

- The refuge spaces and their adjacent spaces should use different lighting systems and there should be a separation based on the functionality of the space (Dawes \& Ostwald, 2014).

\section{Mystery}

Mystery is a spatial state indicated by the assurance of more information evident by the existence of relatively concealed views or other sensory impetus that intrigues the individual to explore further into the native surroundings (Herzog and Bryce, 2007; Ikemi, 2005; Kaplan et al., 1989). The basic understanding of this pattern comes from psychologists R. Kaplan and S. Kaplan's (1989) claim that people need only 2 basic things from environment which are 'to understand' and 'to explore'. Mystery is a useful pattern that can be utilized to modify spaces in indoor and outdoor including walkways, entrances, plazas and buffer spaces.

Robie House designed by Organic Architecture pioneer Frank Lloyd Wright in prairie style has several aspects of mystery and biophilia as it hides the information from the visitor and there is a sense of control with the occupant. The long overhangs of shading devices and indirect entrance are two distinct ways to enhance the characteristics of mystery in a building. 

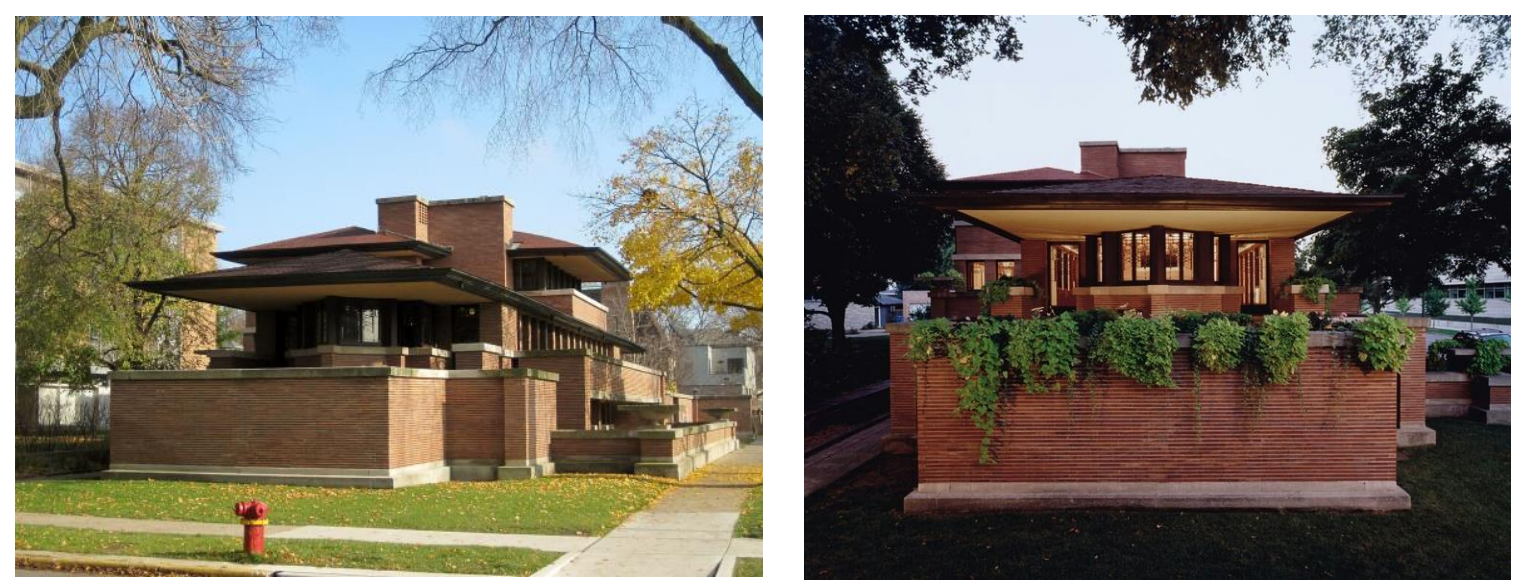

Fig. 19. Robie House by F.L. Wright in Illinois (Chicago) built in Prairie style is still considered one of the best examples of mystery as it does not reveal the main entry in any of its elevations and creates an intriguing interest for visitors. The long overhanging shading creates dark shadows and adds to the mystery of design.

Emerging design parameters to attain quality in Mystery pattern:

- Use of curved edges is recommended as they play a more significant role in comparison to pointed edges while guiding people's movement along them (Browning et al., 2014).

- Speed of movement of people through the space is a considerable factor for mystery as it enhances the small or large nature of the space in fractions of time. Design should control speed of movement through offering distractions and mild obstructions in the pathway (Fayazi, 2014).

- Dramatic use of shade and shadow can add to the mystery of the space (Stewart-Pollack and ASID, 2006).

- Elements with unprecedented organic growth like planters and shrub rails serve as the natural modulators of fear and surprise for the pedestrian (Van Wieren and Kellert, 2013). 


\section{Risk / Peril}

Risk or Peril can be stipulated as a combination of threat and associated safety (Ryan et al., 2014). Environment has a way of revealing itself through creation of certain border parameters as a limit line, this occurs in an environment that is capable of running multiple activities altogether (Fisher and Pedersen, 1996). For example, the first glance enrages fear or a feeling of risk while looking at a façade, which does not have a supporting wall, or a guiding handrail, the design however makes people feel safe and forget this fear when they walk along the same space (Movahed, 2015).

Risk can be a result of a response situation triggered through the reflexes as a learned mitigation and defence mechanism against an alleged danger. When the same risk is ruled out as a reason of causing harm, it ensures safety and becomes a trust element. The levels of danger and the level of control addresses whether it is risk or actual fear (Rapee, 1997). Risk / Peril has the task of intriguing people with curiosity, gain attention and refresh the memory to enhance their problem solving skills.

Emerging design parameters that can be used to attain quality in Risk / Peril pattern:

- Risk / Peril should be approached with precision, as it is a sensitive element for human psychology. Its user base must be well defined and precisely targeted (Honga et al., 2017).

- The element of safeguarding the user must not create an overwhelming environment, which kills the possibility of risk. Risk should be kept as the end limit for the user, certain yet undefined (Zari, 2017). 

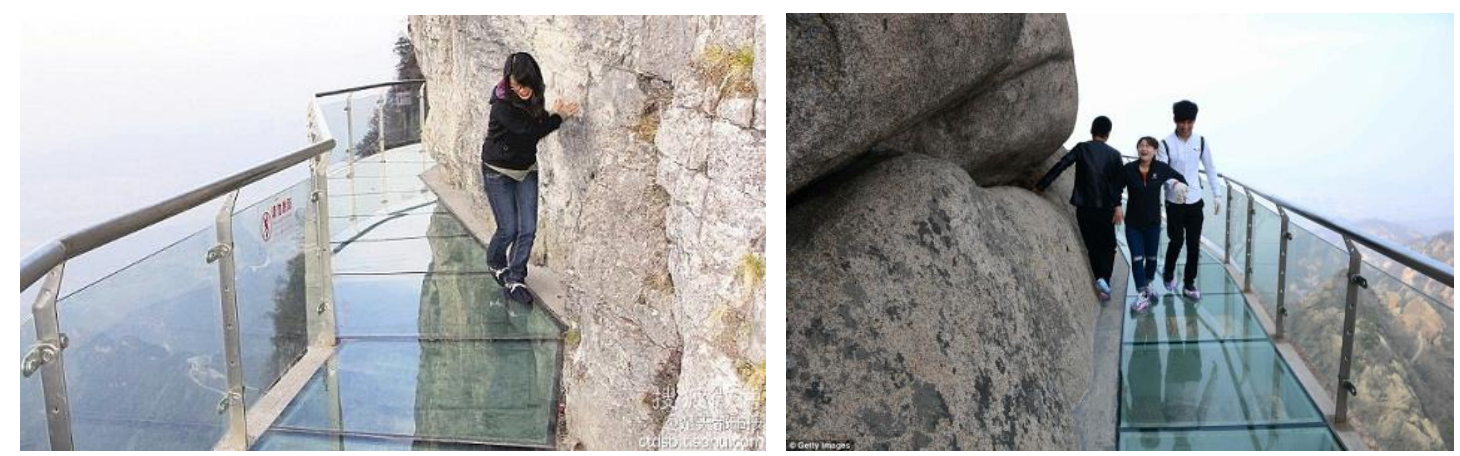

Fig. 20. Glass Skywalk at Tianmen Mountain in Zhangjiajie National Forest Park, China. The initial reaction of the tourists is to stay away from the floorglass and be close to the rock-side..

Once the brain eliminates the risk then the walk becomes usual and adventure seeking.

One of the best examples of risk / peril can be seen in the glass skywalks where the users face acrophobia through walking on a safeguarding walkway experiencing groundlessness (Deriu, 2017). In that case, their safety is certain yet they are subjected to take the risk. Skywalks are built as safe and highly controlled environments; they are expected to provoke the user's acrophobia by subjecting them to the view below their feet. The structure built up of multi layered tampered glass ensures a sense of safety. This experience surpasses the visual senses to such an extent that it may call upon the brain to create a sensation of dizziness (Yardley and Redfern, 2001). Furthermore, sensory situation activates the sixth sense of the body traditionally called 'kinaesthesia' i.e., muscle sense (Stillman, 2002).

\section{CONCLUSION}

Biophilia has been a part of human habitats since twelve millenniums and had felt a setback during the rise of the machine-oriented world in the last 250 years. Biophilic architecture acts as a symposium of technology, applied sciences and architecture by aptly following the nature and its processes. The Biophilia hypothesis by Kellert as well as the 14 patterns by Browning, Clancy and Ryan have laid down the rail work for the further development and research in this 
realm. Biophilic design has arguably put its claim in favour of sustainability, human well-being and based upon the available research literature its merits outlive its demerits on a comparative level and establishes the idea that biophilia although a part of human life is also a sustainable and healthy approach for its future. The future belongs to the cities and while dealing with those highly densified built-environments the scope for nature has to be discussed in the context of human health and well-being.

On the architecture frontiers, biophilia should not be seen as only a kind of luxury aesthetic adaptation in design. It has existed for all of humanity since the beginning of time and it has to be given relevant space in architecture so that there can be a positive impact on the mental health of the population and its immediate surroundings in the most suitable way possible. Multidisciplinary approach has to be adopted in order to conduct further research within the directives of biophilic design on case-to-case basis to find out the preference, productivity and efficiency under certain set of criteria. It can include the weightage of each of the 14 patterns of biophilic design or the development of a more comprehensive and analytic tool like the Biophilic Quality Index (BQI) proposed by Malaysian Architect K. Yeang. Detailed research with respect to the different aspects like economics, use of energy and health in biophilic design must be taken in accordance with the issues like absenteeism and presenteeism for work environments. If humans do not evolve to a point where they can live without nature, then biophilia has a long journey to thrive. There is an optimistic possibility that with the guidelines of LEED and environmental sustainability directives, a lot more can be targeted for expanding the scope of sustainability through biophilic design.

\section{REFERENCES}


Addington, M., \& Schodek, D. (2012). Smart Materials and Technologies in Architecture: For the Architecture and Design Professions. Routledge.

Alexander, C., Ishikawa, S., Silverstein, M., Jacobson, M., Fiksdahl-King, I., and Angel, S. (1977). A pattern language: Towns, buildings, construction (center for environmental structure).

Alexandri, E., \& Jones, P. (2006, September). Ponds, GreenRoofs, pergolas and high albedo materials; which cooling technique for urban spaces. In proceedings of the 23rd Conference of Passive and Low Energy Architecture, Geneva, Switzerland.

Almusaed, A. (2010). Biophilic and bioclimatic architecture: Analytical therapy for the next generation of passive sustainable architecture. Springer Science and Business Media.

Alvarsson, J. J., Wiens, S., and Nilsson, M. E. (2010). Stress recovery during exposure to nature sound and environmental noise. International journal of environmental research and public health, 7(3), 1036-1046.

Appleton J. (1996). The experience of landscape. Chichester: Wiley.

ASHRAE (2013). Standard 55 - Thermal Environmental Conditions for Human. The American Society of Heating, Refrigerating and Air-Conditioning Engineers

Bakó-Biró, Z., Clements-Croome, D. J., Kochhar, N., Awbi, H. B., and Williams, M. J. (2012). Ventilation rates in schools and pupils' performance. Building and Environment, 48, 215-223.

Barton, J., and Pretty, J. U. L. E. S. (2010). Urban ecology and human health and wellbeing. Urban ecology, 202-229. 
Beatley, T. (2011). Biophilic Cities: What Are They?. In Biophilic Cities (pp. 45-81). Island Press, Washington, DC.

Benfield, J. A., Taff, B. D., Newman, P., and Smyth, J. (2014). Natural sound facilitates mood recovery. Ecopsychology, 6(3), 183-188.

Berman, M. G., Kross, E., Krpan, K. M., Askren, M. K., Burson, A., Deldin, P. J., ... and Jonides, J. (2012). Interacting with nature improves cognition and affect for individuals with depression. Journal of affective disorders, 140(3), 300-305.

Biederman, I., and Vessel, E. A. (2006). Perceptual pleasure and the brain: A novel theory explains why the brain craves information and seeks it through the senses. American scientist, 94(3), 247-253.Browning WD, Ryan CO, Clancy JO. Patterns of biophilic design. New York: Terrapin Bright Green, LLC. 2014.

Boubekri, M. (2008). Daylighting, architecture and health. Routledge.

Brawley, E. C. (2009). Enriching lighting design. NeuroRehabilitation, 25(3), 189-199.

Browning, B. (2014). The Economics of Biophilia: Why designing with nature in mind makes sense.

Browning, W. D., Ryan, C. O., and Clancy, J. O. (2014). Patterns of biophilic design. New York: Terrapin Bright Green, LLC.

Burge, P. S. (2004). Sick building syndrome. Occupational and environmental medicine, 61(2), 185-190.

Caivano, J. L. (2006). Research on color in architecture and environmental design: Brief history, current developments, and possible future. Color Research and Application: 
Endorsed by Inter-Society Color Council, The Colour Group (Great Britain), Canadian Society for Color, Color Science Association of Japan, Dutch Society for the Study of Color, The Swedish Colour Centre Foundation, Colour Society of Australia, Centre Français de la Couleur, 31(4), 350-363.

Carlson, J. A., Sallis, J. F., Conway, T. L., Saelens, B. E., Frank, L. D., Kerr, J., ... \& King, A. C. (2012). Interactions between psychosocial and built environment factors in explaining older adults' physical activity. Preventive medicine, 54(1), 68-73.

Chua, S. J. L., Ali, A. S., and Lim, M. E. L. (2016). Physical environment comfort impacts on office employee's performance. In MATEC Web of Conferences (Vol. 66, p. 00124). EDP Sciences.

Cohen, B. (2006). Urbanization in developing countries: Current trends, future projections, and key challenges for sustainability. Technology in society, 28(1-2), 63-80.

Dalgard, O. S., and Tambs, K. (1997). Urban environment and mental health: a longitudinal study. The British Journal of Psychiatry, 171(6), 530-536.

Dalke, H., Little, J., Niemann, E., Camgoz, N., Steadman, G., Hill, S., \& Stott, L. (2006). Colour and lighting in hospital design. Optics \& Laser Technology, 38(4-6), 343-365.

Dawes, M. J., \& Ostwald, M. J. (2014). Testing the 'Wright Space': using isovists to analyse prospect-refuge characteristics in Usonian architecture. The Journal of Architecture, 19(5), 645-666.

Day, C. (2017). Places of the Soul: Architecture and environmental design as healing art. Routledge. 
Dee, C. (2004). Form and fabric in landscape architecture: a visual introduction. Taylor \& Francis.

DeKay, M., \& Brown, G. Z. (2013). Sun, wind, and light: architectural design strategies. John Wiley \& Sons.

Deriu, D. (2017). Skywalking in the city: Glass platforms and the architecture of vertigo. Emotion, Space and Society.

Diette, G. B., Lechtzin, N., Haponik, E., Devrotes, A., and Rubin, H. R. (2003). Distraction Therapy With Nature Sights and Sounds Reduces Pain During Flexible Bronchoscopya: A Complementary Approach to Routine Analgesia. Chest, 123(3), 941-948.

Dosen, A. S., and Ostwald, M. J. (2013). Prospect and refuge theory: constructing a critical definition for architecture and design. The International Journal of Design in Society, 6(1), $9-24$.

Downton, P., Jones, D., Zeunert, J., and Roös, P. (2017). Biophilic Design Applications: Putting Theory and Patterns into Built Environment Practice. KnE Engineering, 2(2), 5965.

Dubos, R. J., \& Pines, M. (1965). HEALTH AND DISEASE.

Duzenli, Tugba and Tarakci Eren, Emine and Akyol, Duygu. (2017). Concept of sustainability and biophilic design in landscape architecture. Asosjournal-The Journal of Academic Social Science. 5. 43-49. 
Edwards, L., and Torcellini, P. (2002). Literature review of the effects of natural light on building occupants (No. NREL/TP-550-30769). National Renewable Energy Lab., Golden, CO.(US).

El-Zeiny, R. M. A. (2012). Biomimicry as a problem solving methodology in interior architecture. Procedia-Social and Behavioral Sciences, 50, 502-512.

Evans, G. W. (2003). The built environment and mental health. Journal of urban health, 80(4), 536-555.Fayazi, N. (2014). Investigating Interactive Biophilic Wearable Objects (Doctoral dissertation, Carleton University Ottawa).

Fang, L., Wyon, D. P., Clausen, G., and Fanger, P. O. (2004). Impact of indoor air temperature and humidity in an office on perceived air quality, SBS symptoms and performance. Indoor air, 14, 74-81.

Feuerstein, G. (2002). Biomorphic architecture. Menges.

Fisher DE, Pedersen CO. (1996) The heat balance method of calculating building heating and cooling loads. European Directory of Sustainable and Energy Efficient Building.

Fisk, W. J., Black, D., \& Brunner, G. (2012). Changing ventilation rates in US offices: Implications for health, work performance, energy, and associated economics. Building and environment, 47, 368-372.

Freudenberg, N., Galea, S., \& Vlahov, D. (2006). Cities and the health of the public. Vanderbilt University Press.

Friedman, D. S. (2017). Salk Institute: Louis I. Kahn. Companion to the History of Architecture, 1-21.. 
Fromm, Erich. (1973) The Heart of Man, pp. 365-366.

Frumkin, H. (2001). Beyond toxicity1: Human health and the natural environment. American journal of preventive medicine, 20(3), 234-240.

Fuller, R. A., Irvine, K. N., Devine-Wright, P., Warren, P. H., and Gaston, K. J. (2007). Psychological benefits of greenspace increase with biodiversity. Biology letters, 3(4), 390394.

Gaitani, N., Mihalakakou, G., \& Santamouris, M. (2007). On the use of bioclimatic architecture principles in order to improve thermal comfort conditions in outdoor spaces. Building and Environment, 42(1), 317-324.

Ghaffarianhoseini, A., AlWaer, H., Omrany, H., Ghaffarianhoseini, A., Alalouch, C., Clements-Croome, D., and Tookey, J. (2018). Sick building syndrome: are we doing enough?. Architectural Science Review, 61(3), 99-121.

Givoni, B. (1992). Comfort, climate analysis and building design guidelines. Energy and buildings, 18(1), 11-23.

Grahn, P., and Stigsdotter, U. K. (2010). The relation between perceived sensory dimensions of urban green space and stress restoration. Landscape and urban planning, 94(3-4), 264-275.

Hagerhall, C. M., Laike, T., Taylor, R. P., Küller, M., Küller, R., and Martin, T. P. (2008). Investigations of human EEG response to viewing fractal patterns. Perception, 37(10), 1488-1494. 
Herzog, T. R. (1985). A cognitive analysis of preference for waterscapes. Journal of Environmental Psychology, 5(3), 225-241.

Herzog, T. R. (1989). A cognitive analysis of preference for urban nature. Journal of environmental Psychology, 9(1), 27-43.

Herzog, T. R., and Bryce, A. G. (2007). Mystery and preference in within-forest settings. Environment and Behavior, 39(6), 779-796.

Hildebrand, G. (1991). The Wright space: pattern and meaning in Frank Lloyd Wright's houses. Seattle: University of Washington Press.

Holahan, C. (1972). Seating patterns and patient behavior in an experimental dayroom. Journal of Abnormal Psychology, 80(2), 115.

Honga, W. A. N. G., Hanb, L. I. N., and Yun-onc, T. O. N. G. (2017). Foster a Healthy Community Through Active Design and Biophilic Design.

Hu, N., Feng, P., and Dai, G. (2013). The gift from nature: bio-inspired strategy for developing innovative bridges. Journal of Bionic Engineering, 10(4), 405-414.

Ikemi, M. (2005). The effects of mystery on preference for residential facades. Journal of environmental psychology, 25(2), 167-173.

Johnson, M. P., Ladd, H. F., and Ludwig, J. (2002). The benefits and costs of residential mobility programmes for the poor. Housing Studies, 17(1), 125-138.

Joye, Y. (2007). Architectural lessons from environmental psychology: The case of biophilic architecture. Review of general psychology, 11(4), 305. 
Kahn Jr, P. H. (1997). Developmental psychology and the biophilia hypothesis: Children's affiliation with nature. Developmental review, 17(1), 1-61.

Kahn Jr, P. H., Friedman, B., Gill, B., Hagman, J., Severson, R. L., Freier, N. G., ... and Stolyar, A. (2008). A plasma display window? - The shifting baseline problem in a technologically mediated natural world. Journal of Environmental Psychology, 28(2), 192199.

Kamaruzzaman, S. N., and Sabrani, N. A. (2011). The effect of indoor air quality (IAQ) towards occupants' psychological performance in office buildings. Journal Design+ Built, 4(1), 49-61.

Kaplan, R., Kaplan, S., and Brown, T. (1989). Environmental preference: a comparison of four domains of predictors. Environment and behavior, 21(5), 509-530.

Kellert, S., and Calabrese, E. (2015). The practice of biophilic design. Retrieved from biophilic design. com.

Kellert, S. R., Heerwagen, J., and Mador, M. (2011). Biophilic design: the theory, science and practice of bringing buildings to life. John Wiley and Sons.

Kellert, S. R. (2004). Beyond LEED: From low environmental impact to restorative environmental design. Green Roof Infrastructure Monitor, 6(1).

Kellert, S. and Finnegan, B. (2012). Biophilic design : the architecture of life (DVD video, 2012) [WorldCat.org]. [online] Worldcat.org. Available at: http://worldcat.org/title/biophilic-design-the-architecture-of-life/oclc/792741427

Kellert, S. R., and Wilson, E. O. (Eds.). (1995). The biophilia hypothesis. Island Press. 
Kinkade-Levario, H. (2007). Design for water: rainwater harvesting, stormwater catchment, and alternate water reuse. New society publishers.

Lindheim, R., \& Syme, S. L. (1983). Environments, people, and health. Annual review of public health, 4(1), 335-359.

Lee, H. C., and Park, S. J. (2018). Assessment of Importance and Characteristics of Biophilic Design Patterns in a Children's Library. Sustainability, 10(4), 987.

Leslie, S. W. (2008). " A Different Kind of Beauty": Scientific and Architectural Style in IM Pei's Mesa Laboratory and Louis Kahn's Salk Institute. Hist Stud Nat Sci, 38(2), 173221.

Lin, T. P., de Dear, R., \& Hwang, R. L. (2011). Effect of thermal adaptation on seasonal outdoor thermal comfort. International Journal of Climatology, 31(2), 302-312.

Lohr, V. I., Pearson-Mims, C. H., and Goodwin, G. K. (1996). Interior plants may improve worker productivity and reduce stress in a windowless environment. Journal of Environmental Horticulture, 14(2), 97-100..

Lohr, V. I., and Pearson-Mims, C. H. (2006). Responses to scenes with spreading, rounded, and conical tree forms. Environment and Behavior, 38(5), 667-688.

Magnavita, N. (2015). Work-related symptoms in indoor environments: a puzzling problem for the occupational physician. International archives of occupational and environmental health, 88(2), 185-196.

Martin, D., Nettleton, S., Buse, C., Prior, L., \& Twigg, J. (2015). Architecture and health care: a place for sociology. Sociology of health \& illness, 37(7), 1007-1022. 
McMichael, A. J. (2000). The urban environment and health in a world of increasing globalization: issues for developing countries. Bulletin of the World Health Organization, $78,1117-1126$.

McQuaid, M. (1993). Santiago Calatrava: structure and expression. Museum of Modern Art.

Mehta, R., Zhu, R., and Cheema, A. (2012). Is noise always bad? Exploring the effects of ambient noise on creative cognition. Journal of Consumer Research, 39(4), 784-799.

Meisel, A. (2010). LEED materials: A resource guide to green building (Vol. 1). New York: Princeton architectural press.

Michl, J. (1995). Form follows WHAT. The modernist notion of function as a carte blanche, $1,20-31$.

Mills, P. R., Tomkins, S. C., \& Schlangen, L. J. (2007). The effect of high correlated colour temperature office lighting on employee wellbeing and work performance. Journal of circadian rhythms, 5(1), 2.

Minah, G. (2012). Colour as idea: The conceptual basis for using colour in architecture and urban design. JAIC-Journal of the International Colour Association, 2.

Mohamed, A. A. A. (2015). Further step beyond green-From distractive, to balance, towards restorative built environment. HBRC journal.

Movahed, K. (2015). Study People and Nature Connection in Built Environment to verify Aqa-Bozorg Mosque as Biophilic Design. Urban managment No.40 Automn 2015. 241252. 
Nash, L. (2006). Inescapable ecologies: A history of environment, disease, and knowledge. Univ of California Press.

Nordh, H., Hartig, T., Hagerhall, C. M., and Fry, G. (2009). Components of small urban parks that predict the possibility for restoration. Urban forestry and urban greening, 8(4), 225-235.

O'Campo, P., Rao, R. P., Gielen, A. C., Royalty, W., and Wilson, M. (2000). Injuryproducing events among children in low-income communities: the role of community characteristics. Journal of Urban Health, 77(1), 34-49.

O'Connor, Z. (2011). Colour psychology and colour therapy: Caveat emptor. Color Research \& Application, 36(3), 229-234.

Öhman, A., and Mineka, S. (2001). Fears, phobias, and preparedness: toward an evolved module of fear and fear learning. Psychological review, 108(3), 483.

Olesen, B. W., and Brager, G. S. (2004). A better way to predict comfort: The new ASHRAE standard 55-2004.

Olgyay, V., Olgyay, A., Lyndon, D., Olgyay, V. W., Reynolds, J., and Yeang, K. (1963). Design with climate: bioclimatic approach to architectural regionalism (Vol. 26). Princeton, NJ: Princeton University Press.

Orians, G. H., and Heerwagen, J. H. (1992). Evolved responses to landscapes.

Osterhaus, W. K. (2005). Discomfort glare assessment and prevention for daylight applications in office environments. Solar Energy, 79(2), 140-158. 
Pacheco-Torgal, F., and Jalali, S. (2011). Cementitious building materials reinforced with vegetable fibres: A review. Construction and Building Materials, 25(2), 575-581.

Pegas, P. N., Alves, C. A., Evtyugina, M. G., Nunes, T., Cerqueira, M., Franchi, M., ... and Freitas, M. C. (2011). Seasonal evaluation of outdoor/indoor air quality in primary schools in Lisbon. Journal of Environmental Monitoring, 13(3), 657-667.

Pelli, C. (1996). Designing with colour. Architectural Design, (120), 26-29.

Quessada, M. P., Clement, P., Oerke, B., and Valente, A. (2008). Human Evolution in Science Textbooks from Twelve Different Countries. Science Education International, 19(2), 147-162.

Rao R. (2014). Biomimicry in architecture. International Journal of Advanced research in Civil, Structural, Environmental and Infrastucture Engineering and Developing. 2014;1(3):101-7.

Rapee, R. M. (1997). Perceived threat and perceived control as predictors of the degree of fear in physical and social situations. Journal of Anxiety Disorders, 11(5), 455-461.

Renalds, A., Smith, T. H., and Hale, P. J. (2010). A systematic review of built environment and health. Family and community health, 33(1), 68-78.

Ritter, A. (2007). Smart materials in architecture, interior architecture and design. Walter de Gruyter.

Rubinowicz, P. (2000). Chaos and geometric order in architecture and design. Journal for Geometry and Graphics, 4(2), 197-207. 
Ruddell, E. J., and Hammitt, W. E. (1987). Prospect refuge theory: A psychological orientation for edge effect in recreation environments. Journal of Leisure Research, 19(4), 249-260.

Ryan C. (2015). Non-Rhythmic Sensory Stimuli: Give Yourself a Break! Retrieved from terrapinbrightgreen.com

Ryan, C. O., Browning, W. D., Clancy, J. O., Andrews, S. L., and Kallianpurkar, N. B. (2014). Biophilic design patterns: emerging nature-based parameters for health and wellbeing in the built environment. International Journal of Architectural Research: ArchNetIJAR, 8(2), 62-76.

Rydin, Y., Bleahu, A., Davies, M., Dávila, J. D., Friel, S., De Grandis, G., \& Lai, K. M. (2012). Shaping cities for health: complexity and the planning of urban environments in the 21st century. The Lancet, 379(9831), 2079-2108.

Salingaros, N. A., and Masden, I. I. (2006). KG (2008). Neuroscience, the natural environment, and building design. Kellert SR, Heerwagen J., Mador M.(ed. s), Biophilic Design: The Theory, Science and Practice of Bringing Buildings to Life, John Wiley, New York, pp59-83.

Salingaros, N. A. (2012). Applications of the golden mean to architecture. Meandering through mathematics, 21 .

Sandifer, S. A. (2009, June). Using the Landscape for Passive Cooling and Bioclimatic Control: Applications for higher density and larger scale. In 26th conference on passive and low energy architecture, Quebec City, Canada (pp. 22-24). 
Sclar, E. D., Garau, P., \& Carolini, G. (2005). The 21st century health challenge of slums and cities. The Lancet, 365(9462), 901-903.

Seidman, M. D., and Standring, R. T. (2010). Noise and quality of life. International journal of environmental research and public health, 7(10), 3730-3738.

Seppanen, O., Fisk, W. J., and Lei, Q. H. (2006). Effect of temperature on task performance in office environment.

Sharifi, M., and Sabernejad, J. (2016). Investigation of Biophilic architecture patterns and prioritizing them in design performance in order to realize sustainable development goals. European Online Journal of Natural and Social Sciences: Proceedings, $5(3$ (s)), pp325.

Singh, T., and Kandari, L. S. (2012). Rainwater harvesting in the Wake of Climate Change: A Case Study from Shimla city, Himachal Pradesh. Universal Journal of Environmental Research and Technology, 2(4).

Soderlund, J., and Newman, P. (2017). Improving Mental Health in Prisons through Biophilic Design. The Prison Journal, 97(6), 750-772.

Song, C., Ikei, H., and Miyazaki, Y. (2016). Physiological effects of nature therapy: A review of the research in Japan. International journal of environmental research and public health, 13(8), 781.

Spencer, S. T. A. C. I. E., \& Baum, A. N. D. R. E. W. (1997). Architecture and health. Baum, A., Newman, St., Weinman, j., West, R. e McManus. 
Stewart-Pollack, J., and ASID, I. (2006). Biophilic design. Ultimate Home Design, (04), $36-41$.

Stigsdotter, U. (2005). Landscape architecture and health (Vol. 2005, No. 55).

Stillman, B. C. (2002). Making sense of proprioception: the meaning of proprioception, kinaesthesia and related terms. Physiotherapy, 88(11), 667-676.

Takki, T., Villberg, K., Hongisto, V., Kosonen, R., and Korpi, A. (2011). A Continuous and Proactive Process to Enhance Well-being Indoors. In Sick Building Syndrome (pp. 353370). Springer, Berlin, Heidelberg.

Tregenza, P., \& Loe, D. (2013). The design of lighting. Routledge.

Tsunetsugu, Y., Lee, J., Park, B. J., Tyrväinen, L., Kagawa, T., and Miyazaki, Y. (2013). Physiological and psychological effects of viewing urban forest landscapes assessed by multiple measurements. Landscape and Urban Planning, 113, 90-93.

Ulrich, R. S., Simons, R. F., Losito, B. D., Fiorito, E., Miles, M. A., and Zelson, M. (1991). Stress recovery during exposure to natural and urban environments. Journal of environmental psychology, 11(3), 201-230.

United Nations. (2015). Transforming Our World: The 2030 Agenda For Sustainable Development (pp. 20-21). United Nations.

United States Environmental Protection Agency. (1991) Air and Radiation (6609J) Research and Development (MD-56) February 1991 
Van den Berg, A. E., Koole, S. L., and Van der Wulp, N. Y. (2003). Environmental preference and restoration:(How) are they related?. Journal of environmental psychology, 23(2), 135-146.

Van Wieren, G., and Kellert, S. R. (2013). The Origins of Aesthetic and Spiritual Values in Children's Experience of Nature. Journal for the Study of Religion, Nature and Culture, 7(3).

Wargocki, P., and Wyon, D. P. (2006). Research report on effects of HVAC on student performance. ASHRAE journal, 48(10), 22.

Weich, S., Blanchard, M., Prince, M., Burton, E., Erens, B. O. B., and Sproston, K. (2002). Mental health and the built environment: Cross-sectional survey of individual and contextual risk factors for depression. The British Journal of Psychiatry, 180(5), 428-433.

White, M., Smith, A., Humphryes, K., Pahl, S., Snelling, D., and Depledge, M. (2010). Blue space: The importance of water for preference, affect, and restorativeness ratings of natural and built scenes. Journal of Environmental Psychology, 30(4), 482-493.

Wilson, E.O. (1984). Biophilia, Harvard University Press.

Wilson, E.O. (2002) The Future of Life. Alfred A. Knopf, New York.

Wolch, J. R., Byrne, J., \& Newell, J. P. (2014). Urban green space, public health, and environmental justice: The challenge of making cities 'just green enough'. Landscape and urban planning, 125, 234-244.

World Health Organization. (2007). Global age-friendly cities: A guide. World Health Organization. 
Wyon, D. P. (2004). The effects of indoor air quality on performance and productivity. Indoor air, 14(7), 92-101.

Yardley, L., and Redfern, M. S. (2001). Psychological factors influencing recovery from balance disorders. Journal of anxiety disorders, 15(1-2), 107-119.

Yin, J., Zhu, S., MacNaughton, P., Allen, J. G., and Spengler, J. D. (2018). Physiological and cognitive performance of exposure to biophilic indoor environment. Building and Environment, 132, 255-262.

Zari, M. P. (2017). What makes a city 'biophilic'? Observations and experiences from the Wellington Nature Map project. In Back to the Future: The next 50 years, 51 st International Conference of the Architectural Science Association (pp. 105-114). The Architectural Science Association and Victoria University of Wellington Wellington, New Zealand. 